\title{
Dense ampeliscid bed on the Canadian Beaufort Shelf: an explanation for species patterns
}

\author{
Kathleen E. Conlan ${ }^{1}\left[\right.$ [D Ed A. Hendrycks ${ }^{1} \cdot$ Alec E. Aitken $^{2}$
}

Received: 14 March 2018 / Revised: 27 September 2018 / Accepted: 1 October 2018 / Published online: 17 October 2018

(c) The Author(s) 2018

\begin{abstract}
The first known ampeliscid (Amphipoda: Ampeliscidae) bed for the Canadian Arctic was reported in 2013 from the Canadian Beaufort Shelf (CBS), but species patterns were not examined. This study examines their distributions relative to differences in life strategies and environmental variables. The intent is to build a better understanding of this highly productive system in comparison with ampeliscid beds in the neighboring Bering and Chukchi Seas which are important resources for higher trophic level consumers. Data from 412 samples collected to $1000 \mathrm{~m}$ depth over 2002-2009 indicate that there are at least eight ampeliscid species on the CBS. Five occur elsewhere in polar and temperate latitudes and three may be new to science or are species complexes. All are limited to bottom temperatures $<0.41{ }^{\circ} \mathrm{C}$. Congeners do not distribute coherently (Similarity Profiles analysis, $p<0.05$ ). Resource-demanding Ampelisca macrocephala (max. 8467 ind. $\mathrm{m}^{-2}$ ) dominates Byblis spp. and Haploops laevis on the shelf enriched by wind-driven upwelling but dominance switches with depth to Haploops tubicola, Haploops sibirica and Haploops sp. Obligate suspension feeding with adaptations for fine particle capture enables deep living while abundance dominants supplement their diets with deposit feeding and predation. The ampeliscids may facilitate other amphipods by providing attachment sites on their tubes. Polychaetes may facilitate the ampeliscids by bringing buried resources to the surface. Given that the CBS is undergoing substantial environmental change, we recommend the CBS ampeliscids for monitoring its environmental regime to complement ongoing monitoring in other polar and temperate ampeliscid beds.
\end{abstract}

Keywords Ampeliscid amphipods · Arctic · Beaufort - Cape Bathurst

\section{Introduction}

Ampeliscid amphipods in the eastern Russian and western North American Arctic are a key resource for Pacific gray whales (Eschrichtius robustus), which travel from as far as Baja California, Mexico to the Bering and Chukchi Seas to forage there during the summer ice-free season (Highsmith et al. 2007; Fadeev 2011; Budnikova and Blokhin 2012;

Electronic supplementary material The online version of this article (https://doi.org/10.1007/s00300-018-2417-z) contains supplementary material, which is available to authorized users.

Kathleen E. Conlan

kconlan@nature.ca

1 Canadian Museum of Nature, Station D, P. O. Box 3443, Station D, Ottawa, ON K1P 6P4, Canada

2 Department of Geography and Planning, University of Saskatchewan, 117 Kirk Hall, 117 Science Place, Saskatoon, SK S7N 5C8, Canada
Heide-Jørgensen et al. 2012; Schonberg et al. 2014; Demchenko et al. 2016; Brower et al. 2017). Ampeliscids are one of the most abundant prey species, because they form dense beds of self-made tubes, with a biomass up to $300 \mathrm{~g}$ wet wt $\mathrm{m}^{-2}$ (Heide-Jørgensen et al. 2012). These Arctic ampeliscids have high caloric value for gray whale predators (Highsmith and Coyle 1990; Tu et al. 2015; Demchenko et al. 2016) and along with $\sim 150$ other prey species provide $\sim 220,800 \mathrm{~kg}$ of food per gray whale during the gray whales' $\sim 184$ day residence in the Arctic (Jones and Swartz 2009). Ampeliscids are also a resource for demersal fish, nemerteans, polychaetes and sea stars, and also their associated parasites (Mills 1967; Franz and Worley 1982; McDermott and Snyder 1988; Franz and Tanacredi 1992; Sheader 1998; Cui et al. 2012). Surface feeding seabirds consume ampeliscids when they are brought to the surface by benthic feeding gray whales (Grebmeier and Harrison 1992) and pelagic fish prey on ampeliscids migrating into the water column to disperse or mate (Borowsky and Aitken-Ander 1991; Sudo and Azeta 
1992; Dauvin and Zouhiri 1996). Migrating ampeliscids are also available to Arctic phocid seals, which eat amphipods along with many other invertebrates and fish (Dehn et al. 2007; Giraldo et al. 2016). Benthic feeding seabirds either consume ampeliscids directly or benefit indirectly when the ampeliscid tube mats enhance growing conditions for their bivalve prey (MacKenzie et al. 2006; Loring et al. 2013). Because of their reliance on dense prey assemblages, top predators are sentinels of change in the Arctic and essential food resources for indigenous cultures (Moore et al. 2014).

Ampeliscid beds occur in more temperate parts of the Atlantic and Pacific where they may have been a resource for Atlantic gray whales before the whales were exterminated by whalers about 300 years ago (Jones and Swartz 2009). Conlan et al. (2013) located the first ampeliscid bed known for the Canadian Arctic, situated on the Canadian Beaufort Shelf (CBS) (= Mackenzie Shelf, Fig. 1). Biomass of the ampeliscids was comparable to that in the Bering and Chukchi feeding area (up to $307.3 \pm 51.2 \mathrm{~g}$ wet $\mathrm{wt} \mathrm{m}^{-2}$ ) and there was evidence that gray whales also visited the CBS ampeliscid bed, in spite of its being $1600 \mathrm{~km}$ to the east of the prime gray whale feeding grounds (Conlan et al. 2013). Wind-driven upwelling of plankton onto the CBS was thought to sustain the ampeliscid bed, which covered an estimated $2550 \mathrm{~km}^{2}$ of the CBS (Conlan et al. 2013). As in the Bering and Chukchi beds, the CBS ampeliscid bed was multi-specific, comprising species of Ampelisca, Byblis and Haploops.

There are 238 species of Ampelisca, 85 species of Byblis and 29 species of Haploops described world-wide (Horton et al. 2018). Most are little known beyond their morphology and collection data. Only a few are known to form dense beds (Rigolet et al. 2012; Conlan et al. 2013), but knowledge of how the ampeliscids distribute and interact within these beds can provide an important understanding of how their sensitivities and resilience may affect top predators (Highsmith and Coyle 1991; Coyle and Highsmith 1994). The CBS ampeliscid bed has not been previously analyzed for its species content, although it is known to be compositionally similar (but not identical) to the well-studied Bering and Chukchi beds to the west (Conlan et al. 2013). The purpose of this paper is to gain a better understanding of the CBS ampeliscid bed and its surrounding populations. We ask whether all species are coherently distributed there, suggesting that they all respond similarly to environmental conditions. If this is the case, we ask whether their distributions can be related to differences in individual or groups of abiotic variables as well as to biotic variables such as life history, feeding behavior and morphology. Furthermore, we ask whether other benthic community members are coherently distributed with one or more ampeliscid species and if so, how they may interact. The overall goal is to gain an understanding of the drivers for the ampeliscids as well as their interactions with other community members on the CBS. This is important as the proportion of ampeliscid species may change in the future to a different species complex depending on individual vulnerabilities and this may affect the size of the ampeliscid bed and the species that interact with them. Recent record warm winters have occurred in the Arctic with record low sea ice and high sea surface temperatures that have changed atmospheric circulation and a reversal in sea ice drift through the Beaufort Sea (Moore et al. 2018; Petty 2018). Summer sea-ice extent in 2018 is 1.59 million square kilometers below the 1981-2010 long-term average sea ice extent, the seventh lowest August extent in the satellite record (National Snow \& Ice Data Center 2018). Much of the Arctic's multi-year ice is being lost in the Beaufort Sea, and atmosphere and ocean are substantially changing (Carmack and Macdonald 2002; Barber et al. 2008; Carmack et al. 2016; Tooth and Tschudi 2018). Increased primary and secondary productivity from increasing light availability are not necessarily a consequence of sea ice loss due to increased stratification, but increased freshwater inflow, turbidity, acidification, precipitation, storms and shelf-edge upwelling also are being recorded or predicted in the Arctic (Carmack et al. 2016). Increased penetration and residence time of warm Pacific and Atlantic water masses in the Arctic Ocean are also being observed (Wassmann et al. 2011). Taxonomic and functional shifts are a logical consequence of such changes with poleward shifts of generalists and changing characteristics of residents (Wassmann et al. 2011; Kortsch et al. 2015; Renaud et al. 2015). A shift of ampeliscid content on the CBS to smaller species could have repercussions for the ampeliscids and their associates and predators (Coyle and Highsmith 1994) but a longer growing season could enhance ampeliscid growth and dominance by large species in nutrient-enriched passages and channels of shelf archipelagos (Carmack et al. 2016), thus favouring their vertebrate predators.

\section{Materials and methods}

\section{Sampling locations}

Sampling covered the area $69.32-72.38^{\circ} \mathrm{N}$, $121.28-139.05^{\circ} \mathrm{W}$ and depth $4.8-1000 \mathrm{~m}$. There were 412 samples analyzed from 194 sites over 2002-2009 in a longitudinal range of $670 \mathrm{~km}$ from Amundsen Gulf in the east to the Mackenzie Trough in the west. Sample number differs from Conlan et al. (2013) who based a biomass analysis on the full sample collection (540 samples) which did not require full faunal identification. Conlan et al. (2008) based their macrofaunal analysis on a smaller subset (134 samples) that had been fully identified at the time. Conlan et al. (2008) found that macrofaunal patterns were related 

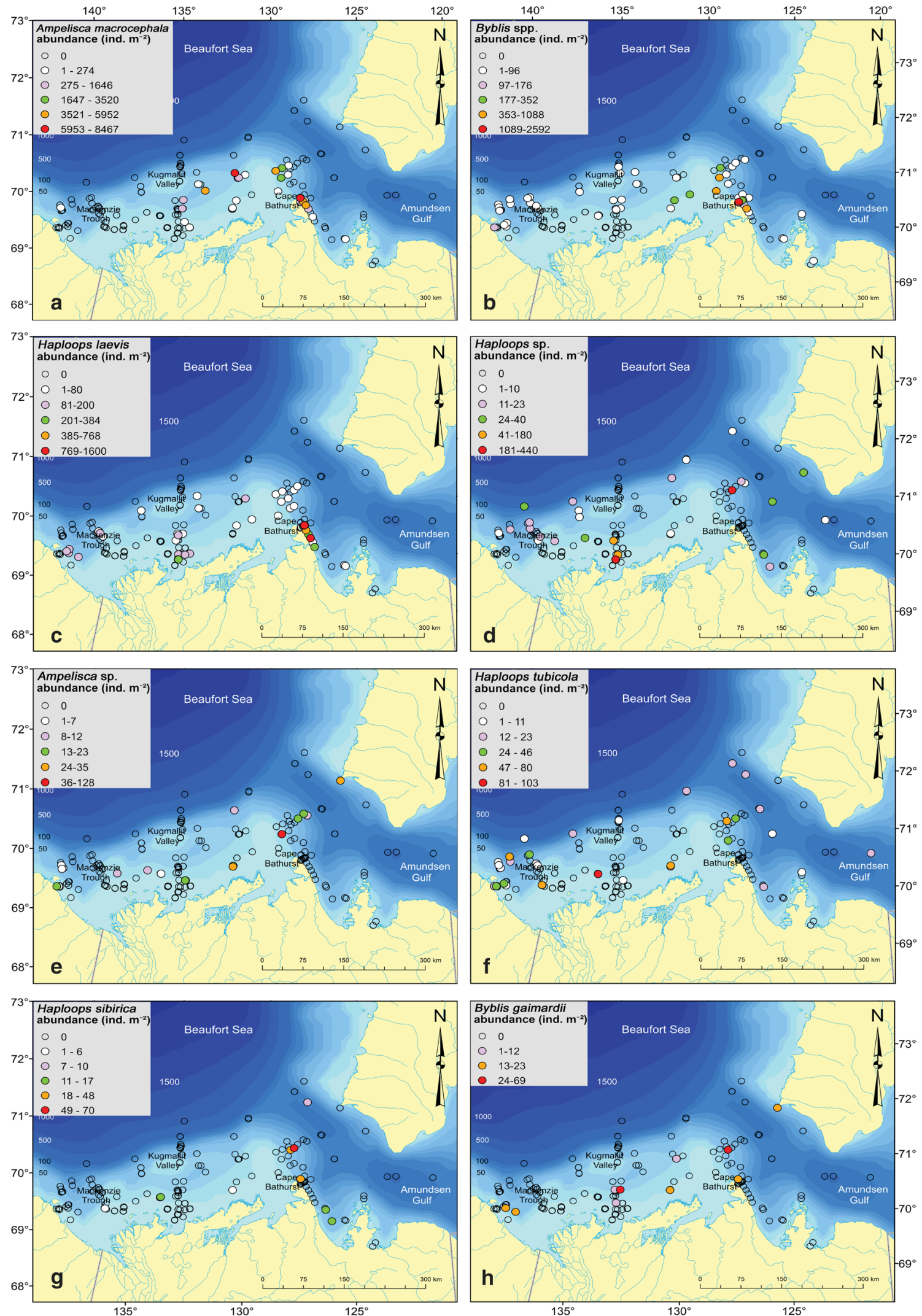

Fig. 1 Distribution of ampeliscid amphipods on the Canadian Beaufort Shelf, with abundance partitioned by the Jenks criterion (Jenks and Caspall 1971) and color coded (left inset of each map). a Ampe-

lisca macrocephala; b Byblis spp.; c Haploops laevis; d Haploops sp.; e Ampelisca sp.; f Haploops tubicola; g Haploops sibirica; $\mathbf{h}$ Byblis gaimardii 
to depth and depth-related variables more than to sampling date. Therefore, for this analysis, the 7-year data set is considered to be a single sampling campaign rather than 7 independent campaigns. Species distributions were mapped with ArcGIS 10.2 using color bins for abundance defined by the Jenks iterative method which minimizes within-class differences and maximizes between-class differences (Jenks and Caspall 1971). The projection is North Pole Azimuthal Equidistant. When two or more locations were so close together that they overlapped, the symbol with the greatest value was superimposed on the other(s).

\section{Sampling methods and environmental analyses}

The methods for sampling and identifying biota, bottom water composition and sediment grain size and $\mathrm{C}$ and $\mathrm{N}$ levels are as described in Conlan et al. (2008, 2013). Briefly, the samples were collected by $0.25 \mathrm{~m}^{2}$ box core $(n=349)$ or by $0.1 \mathrm{~m}^{2}$ van Veen grab $(n=63)$. At the time of sampling, each box core sample was partitioned into biotic and sediment sample areas. The biotic area was $0.14 \pm 0.04 \mathrm{~m}^{2}(n=349)($ mean $\pm \mathrm{SD})$ with extraction to $15 \mathrm{~cm}$ depth. The van Veen grab samples were taken separately for biota and sediment. The biota were elutriated and the supernatant washed through $0.5 \mathrm{~mm}$ mesh. Heavy biota that remained in the sediment (only large mollusks and polychaetes) were removed by hand. All biota were fixed in 5\% buffered formalin-seawater and preserved in $70 \%$ ethanol, and then identified to the lowest possible level. The ampeliscids were fully identified by one of us (EH), who is an authority on the taxonomy of amphipods. A high powered microscope (Nikon SMZ-U) and current taxonomic literature were used. Taxonomic experts for other taxa are noted in Conlan et al. (2008).

Sediment samples were taken from the surface $2 \mathrm{~cm}$, frozen and analyzed as described in Conlan et al. (2008, 2013). The sediment samples were analyzed for grain size, $\% \mathrm{~N}, \%$ organic $\mathrm{C}$ and $\delta^{13} \mathrm{C}$ at the University of Calgary or the Geological Survey of Canada. For grain size, subsamples $(0.15-0.20 \mathrm{~g}$ if siltier, $0.80-0.90 \mathrm{~g}$ if sandier) were treated with a $30 \%$ solution of $\mathrm{H}_{2} \mathrm{O}_{2}$ to remove the organic matter and then analyzed by a Malvern Instruments Mastersizer 2000 with Hydro G sample dispersion unit. Total carbon was determined by the loss on ignition method in McKeague (1976). $\delta^{13} \mathrm{C}$ was determined by Continuous Flow-Elemental Analysis-Isotope Ratio Mass Spectrometry technology. Total nitrogen was determined by the Kjeldahl digestion procedure in Schuman et al. (1973). Bottom water data were collected from a temperature-conductivity recorder (Sea Bird Instruments SBE37) about $2 \mathrm{~m}$ above the seabed, which is comparable to at-seabed conditions (Conlan et al. 2013).
Species distributions relative to environmental variables

The BEST procedure in Primer v.7 (Clarke et al. 2014) was applied to address the question of whether the ampeliscid abundance patterns correlated with environmental patterns. Environmental values were plotted and transformed by square root if right skewed or by the value's inverse if left skewed and then normalized. Correlated variables (Pearson correlation $>0.8$ ) were reduced to a single variable acting as proxy for the other(s). Combinations of variables to a maximum of 5 were examined. Date of sampling, sampler type and sample area were included to determine whether sampling method influenced the results. Ampeliscid abundances $\mathrm{m}^{-2}$ were calculated from numbers sample $\mathrm{e}^{-1} / \mathrm{sample}$ area and averaged across replicate samples $(n=73,19$ and 102 for 1, 2 and 3 replicates, respectively). Subsequently, they were square root transformed to reduce the overwhelming effect of abundant species.

\section{Coherent species distributions}

The Similarity Profiles (SIMPROF) test in Primer v.7 was applied to determine whether all ampeliscid species on the CBS were distributed similarly or whether there were subgroups that were significantly coherent in distribution. Somerfield and Clarke (2013) developed this non-parametric permutation method to address the inherent difficulties of analyzing species distributions over samples (inverse analysis): non-independence of species distributions, nonmonotonic abundance response to gradients, more species than samples, large variations in abundance, and large variations in species frequency. The method compares species distributions against the null hypothesis of no multivariate structure in the data and detects species subsets that have the same degree of association (i.e., that form a coherent group).

While the ampeliscids were found in 129 sites, 7 sites lacked a full suite of data for all the macrofauna. Therefore, these sites were removed to maintain consistency among SIMPROF tests but included in the BEST analyses which required only the ampeliscid data set. Similarities in distribution were determined by the Index of Association (IA), a Bray-Curtis measure based on standardization by percentage abundance (Bray and Curtis 1957). When two species have exactly the same distribution of percentage abundance across the samples, IA $=100$ (full positive association). If $I A=0$, the species have a fully negative association. A similarity profile was constructed for all species associations with each other (the real similarity profile). Subsequently, a simulated profile of non-association was generated by randomising species' relative proportions separately across the samples (Type 2 SIMPROF; Somerfield and Clarke 2013). The test statistic, $\pi$, is the 
sum of absolute departures of the real similarity profile from a mean profile of non-association, permuted 999 times. The null hypothesis was rejected if the observed $\pi$ was greater than all except $p=5 \%$ of $\pi$ values for a new set of simulated profiles.

If significant species associations existed, Type 3 SIMPROF was applied to explore which species were associated. A dendrogram of species associations was generated by group average sorting. At each node of the tree, a SIMPROF test was run to assess whether the subset of species at that node had a significantly similar association (they formed a coherent group). In this case, the profile of non-association was generated by randomly exchanging the proportional abundance across the species subset independently for each sample and determining $\pi$. After repeating this 999 times, if this exchange altered the similarity profile among the species more than $p=5 \%$ of the time, then the null hypothesis that the species were coherently associated was rejected.

Repeat Type 2 and 3 SIMPROF analyses were run on (1) all eight ampeliscid taxa; (2) incompletely identified ampeliscids merged with their congener; and (3) potentially coherently distributed non-ampeliscids. The purpose of the first SIMPROF analysis was to address the question of whether congeners had significantly similar or dissimilar distributions. The purpose of the second SIMPROF analysis was to examine the effects of mis-identifying specimens. Identification to genus was with $100 \%$ confidence and it was assumed in the first SIMPROF analysis that Byblis spp., Ampelisca sp. and Haploops sp. were different from their named congeners. However, it was possible that these un-named species were actually their named congener but the individuals were too small or damaged to identify conclusively. Accordingly, six combinations of species merges were run by summing the abundances of congeners: (i) Ampelisca sp. + A. macrocephala; (ii) Byblis spp. + B. gaimardii; (iii) Haploops sp. +H. laevis; (iv) Haploops sp. + H. sibirica; (v) Haploops sp. + H. tubicola; and (vi) 1/3 Haploops sp. apportioned to each of $H$. laevis, $H$. sibirica and $H$. tubicola. If the named species maintained their relationships with other species despite being merged with an un-named congener, this gave confidence in the results of the SIMPROF analysis when all taxa were assumed to be separate species. The purpose of the third SIMPROF analysis was to address the question of biological interactions between ampeliscids and non-ampeliscids. This analysis targeted the abundance dominants and common macrofauna that occurred in $>10$ sites on the CBS and co-occurred with at least one of the dominants. Biological characteristics of coherently distributed macrofauna such as taxonomic relatedness, substrate use, feeding mode and known associations with ampeliscids were determined from the literature.

\section{Distribution patterns at Cape Bathurst}

Along a $140 \mathrm{~km}$ stretch to the north and south of Cape Bathurst, 31 samples were taken on the shelf $(12-50 \mathrm{~m})$, shelf-break (59-74 m) and slope (80-119 m) (depth categories defined by Williams and Carmack 2008), with the intent of examining dominant species distribution patterns where previous study had found the ampeliscids to be particularly abundant (Conlan et al. 2008, 2013). Cross-shelf distribution patterns were examined in four transects. Two were run at 66-73 km and 51-52 km north of the tip of Cape Bathurst where the shelf was wide (respectively, running 59-17 and 58-44 km west of an Acoustic Doppler Current Profiler (ADCP) moored at station CA-5 in Williams and Carmack 2008). Termed Wide $\mathrm{N}$ and Wide S, these were 42 and $14 \mathrm{~km}$ long and covered a depth range of 42.4-85.1 m and 39.6-48.2 m, respectively. The two other transects were run at 13-18 km south of the tip of Cape Bathurst where the shelf was narrow (respectively, running 17-14 km and $19-13 \mathrm{~km}$ south of an ADCP moored at station CA6 in Williams and Carmack 2008). Termed Narrow $\mathrm{N}$ and Narrow $\mathrm{S}$, these were 7 and $10 \mathrm{~km}$ long and covered a depth range of 20.9-74.2 m and 12.1-119.2 m, respectively. The Narrow $S$ transect was run in 2007 while the other three were run in 2008.

\section{Results}

There were 10,304 specimens of Ampelisca, 1332 specimens of Byblis and 2051 specimens of Haploops found in 231 of the 412 samples (129 of the 194 sites). These were identified as Ampelisca macrocephala, Ampelisca sp., Byblis gaimardii, Byblis spp., Haploops laevis, H. sibirica, H. tubicola and Haploops sp. (Table 1). Ampelisca macrocephala is the largest species (max. $33 \mathrm{~mm}$ body length) and $H$. sibirica is the smallest (max. $7 \mathrm{~mm}$ ). The others are intermediate, ordered B. gaimardii $>$ H. laevis $>$ H. tubicola $>$ Haploops sp. $=$ Ampelisca sp. $=$ Byblis spp. The five nominal species range outside the Arctic, with $H$. sibirica and $H$. tubicola also occurring in the North Pacific and A. macrocephala, $H$. laevis, H. tubicola and B. gaimardii in the North Atlantic. Haploops tubicola is the most wide ranging and also spans a greater depth range than the others.

The three un-named species were considered to be distinct from the named species, with Byblis spp. possibly comprising more than one species. Ampelisca sp. could have been A. eschrichtii as one sample on the NE shelf of Amundsen Gulf was confirmed to be this species. However, identifications for other samples could not be unequivocally attributed to this species. In addition, 37 Haploops hatchlings were found in $4 \%$ of the samples. These could not be identified confidently to any of the four Haploops species 


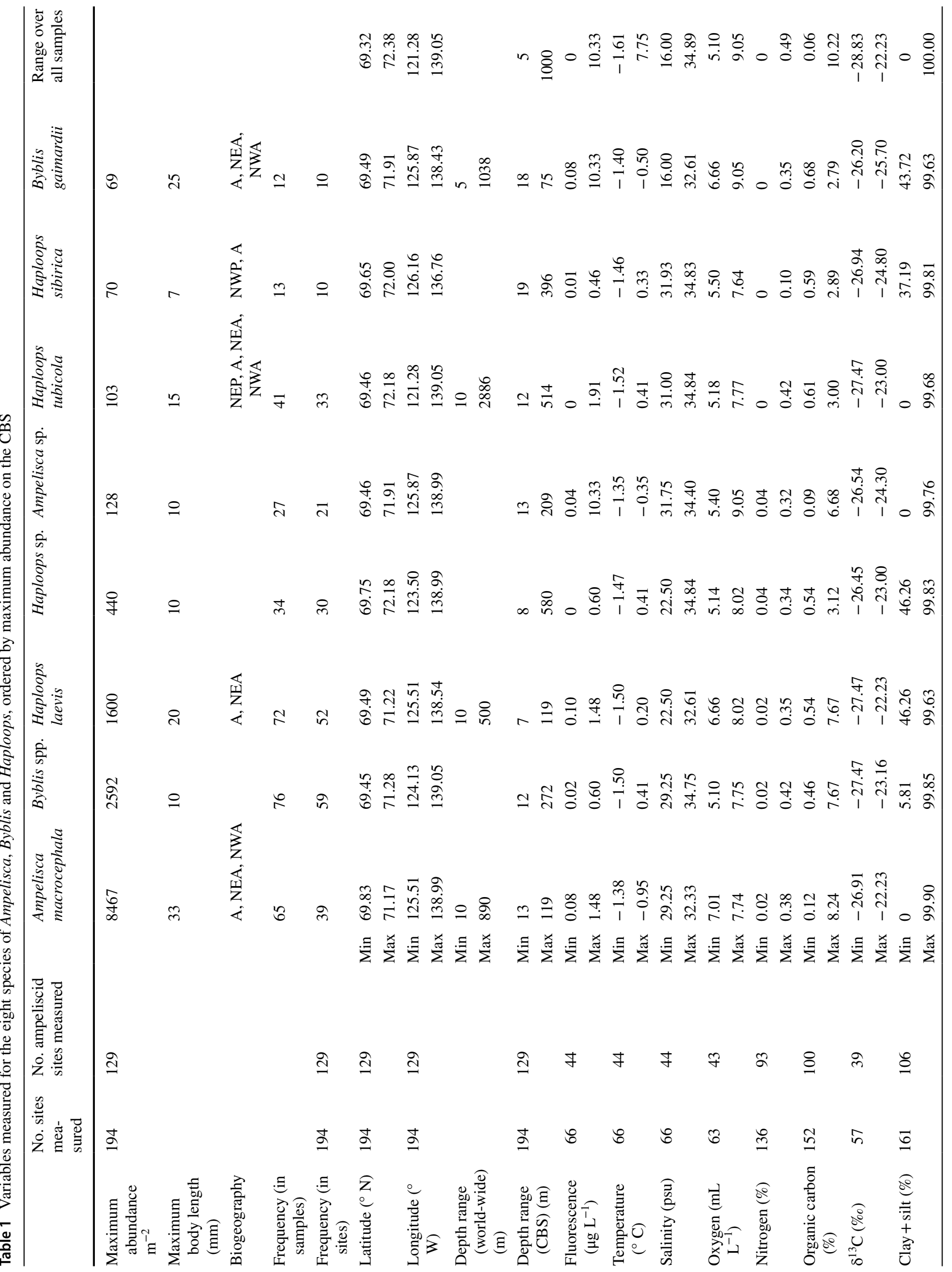




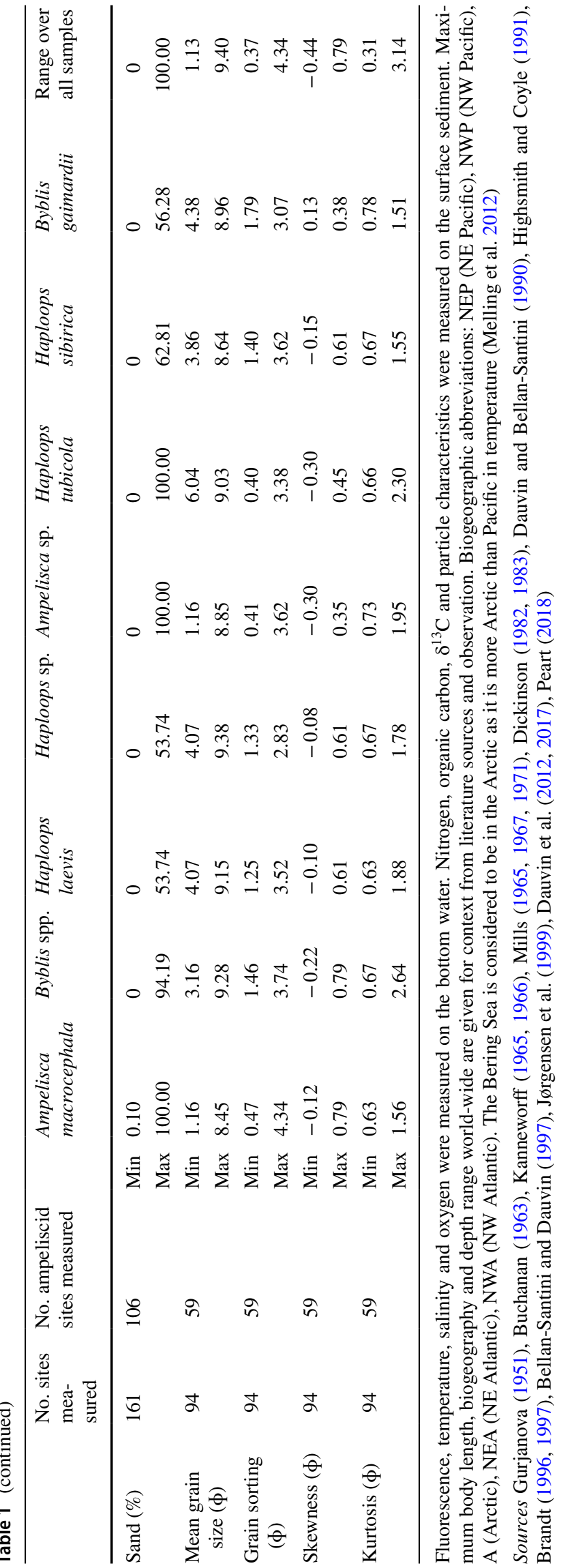

because of their small size and so were excluded from this study.

\section{Distribution patterns over the CBS}

Ampelisca macrocephala (Fig. 1a) was by far the most abundant, with up to 8467 ind. $\mathrm{m}^{-2}$ found on the eastern shelfedge at Cape Bathurst and 5953 ind. $\mathrm{m}^{-2}$ on the shelf-edge to the northwest. Byblis spp. (Fig. 1b) and H. laevis (Fig. 1c) were also found at maximal abundance on the eastern shelfedge of Cape Bathurst but at lower densities (up to 2592 and 1600 ind. $\mathrm{m}^{-2}$, respectively). To the north of Cape Bathurst, the shelf-edge was more gradual. All three were present there but their abundance was at least half their abundance on the steeper slope to the south. All three species ranged to the west of Cape Bathurst but mostly in low numbers relative to the shelf-edge at Cape Bathurst. Of the three, $A$. macrocephala had the most abbreviated distribution (found in 39 sites), being nearly absent from the samples taken west of Kugmallit Valley, with the exception of one site on the western edge of Mackenzie Trough. Byblis spp. and H. laevis were more widespread than A. macrocephala. Byblis spp. were the most frequently found (59 sites), followed by $H$. laevis (52 sites) but their distributions were nearly opposite. Byblis spp. were more abundant offshore than inshore while $H$. laevis showed abundance peaks inshore. Neither was present close to the inflow of the large Mackenzie River.

Collectively, the ampeliscids spanned nearly the full latitudinal and longitudinal range of sampling. Even the five other ampeliscid species (Figs. 1d-h), which were less abundant than the previous three species by close to an order of magnitude, were distributed widely on the CBS. Most showed an abundance peak on the shelf near Kugmallit Valley or on the shelf-edge or slope to the north of Cape Bathurst. Haploops sp., Ampelisca sp. and H. tubicola were moderately frequent (21-33 sites). The two rarest species, $H$. sibirica and $B$. gaimardii, were found at only 10 sites. Few specimens of $H$. sibirica were found away from Cape Bathurst, while B. gaimardii also occurred in proportionally larger numbers on the shelf to the east and west, across Amundsen Gulf, in Kugmallit Valley and on the edge of Mackenzie Trough.

While samples were taken from 5 to $1000 \mathrm{~m}$ depth, the ampeliscids were found between 7 and $580 \mathrm{~m}$. Maximal depths on the CBS were 7-23\% of maximal depths known elsewhere in the world. All species were found close to their minimal depths, though. For all species, the highest abundances occurred on the shelf or shelf-edge. Haploops laevis and the species of Ampelisca and Byblis were restricted to the shelf while Haploops sp., H. tubicola and H. sibirica ranged into the deeper waters of the Beaufort Sea and Amundsen Gulf. 


\section{Environmental summary}

Bottom water fluorescence, temperature, salinity and oxygen were measured at 63-66 of the 194 sites (43-44 of the 129 sites where ampeliscids were present) (Table 1). Most species were found where bottom water fluorescence was low $\left(0-1.91 \mu \mathrm{g} \mathrm{L}^{-1}\right)$. Only Ampelisca sp. and B. gaimardii occurred in the full range sampled $\left(0-10.33 \mu \mathrm{g} \mathrm{L}^{-1}\right)$. Despite sampling at sites with bottom temperatures as high as $7.75{ }^{\circ} \mathrm{C}$, the ampeliscids were found only in the colder bottom water $\left(-1.52\right.$ to $\left.0.41{ }^{\circ} \mathrm{C}\right)$. All species of Haploops occurred in slightly warmer water (max. $\left.0.20-0.41^{\circ} \mathrm{C}\right)$ than species of Ampelisca (max. -0.95 to $-0.35^{\circ} \mathrm{C}$ ). Byblis was more variable (max. -0.51 to $0.41{ }^{\circ} \mathrm{C}$ ). While samples were taken from a bottom salinity range of $16.00-34.89$ psu, most of the ampeliscids occurred in the more saline areas (22.50-34.84 psu). Byblis gaimardii was found in the widest salinity range (16.00-32.61 psu). Bottom water oxygen levels ranged from 5.10 to $9.05 \mathrm{~mL} \mathrm{~L}^{-1}$. The ampeliscids collectively spanned this range, with Byblis spp., H. tubicola and Haploops sp. in the lower part of the range and Ampelisca sp. and B. gaimardii at the upper part of the range.

Surface sediment samples were analyzed at $57-161$ of the 194 sites, with most sites being measured for grain size, $\mathrm{N}$ and organic C. Ampeliscids were present in mostly the full range of $\mathrm{N}$ and org. $\mathrm{C}$ sampled $(0-0.42 \% \mathrm{~N}, 0.09-8.24 \%$ org. C for ampeliscids vs. $0-0.49 \% \mathrm{~N}, 0.06-10.22 \%$ org. C for all samples). Haploops sibirica occurred in a narrower range than the other species (0-0.1\% N, $0.59-2.89 \%$ org. C). Surface sediment $\delta^{13} \mathrm{C}$ content became more enriched with increasing depth. The ampeliscids occurred across nearly the full range of $\delta^{13} \mathrm{C}(-28.83$ to $-22.23 \%)$. Most parts of the CBS had a high clay/silt fraction but isolated areas were up to $100 \%$ sand. Ampelisca macrocephala, Ampelisca sp., Byblis spp. and H. tubicola occurred in both clay/silt and sand while the other species were restricted to a clay/silt fraction $>37 \%$.

\section{Species distributions relative to environmental variables}

Sediment $\%$ clay/silt, $\%$ sand and median grain size were highly correlated (Pearson correlation, $r \geq 0.8$ ) ( $n$ given in Table 1$)$. These were reduced to a single variable (\% clay/ silt) acting as proxy for the others. The BEST analysis identified that depth was the single variable that produced the highest correlation of rank similarity matrices generated by the environmental and ampeliscid distributions over the 129 sites (Spearman rank correlation, $r s=0.110, n=129$ ). The top 10 correlations produced by various combinations of 5 variables ranged from $r s=0.139-0.141$. The best combination of 5 environmental variables was depth, bottom water fluorescence and salinity and sediment org. C and sorting. Replacing salinity with oxygen gave the same correlation $(r s=0.141)$. The lower correlations $(r s=0.139-0.40)$ were with various combinations of these variables with

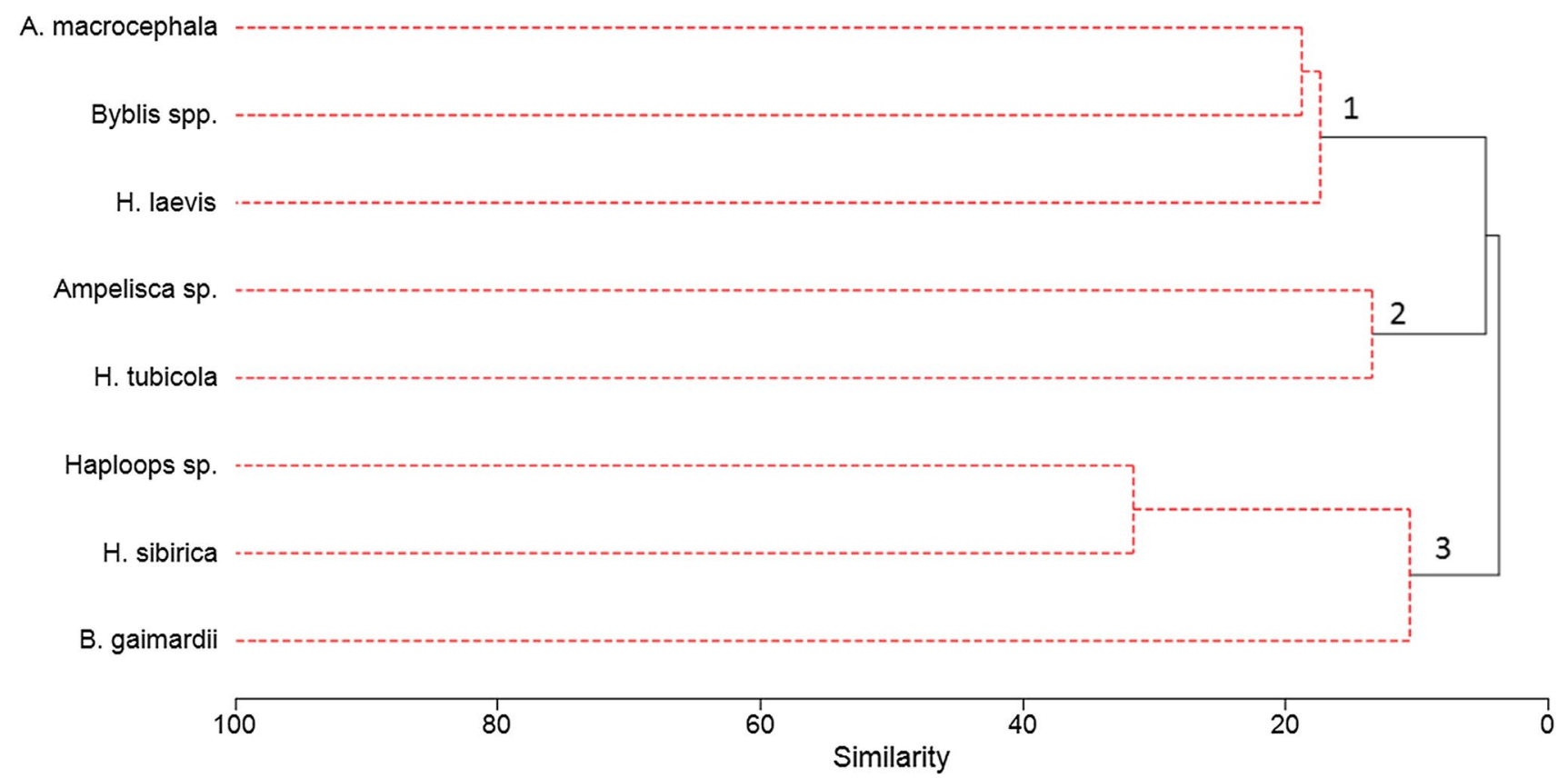

Fig. 2 Dendrogram of $\%$ similarity of the eight ampeliscid species associations. Within each of the three groups linked by a dashed line, the null hypothesis that all pairs of species have the same association cannot be rejected (Type 3 SIMPROF test, $p=0.05$ ). Conversely, subgroupings linked by a solid line have statistical support. $\pi$ values at each of the numbered nodes are given in the text 
temperature added to the 5-variable mix but at no time were sampling methods part of the combinations that gave the highest correlations.

Depth was most correlated with increasing bottom water salinity (Pearson correlation, $r=0.50$ ), followed by increasing surface sediment $\delta^{13} \mathrm{C}(r=0.47)$ and declining bottom water oxygen $(r=0.37)$ ( $n$ given in Table 1$)$. Other variables were less correlated $(r<0.30)$. BEST analysis after removal of depth and sampling variables reduced the correlations of the abiotic with the biotic rank similarity matrices. The single variable that produced the highest correlation ( $r s=0.074)$ was surface sediment sorting. Slightly higher correlations ( $r s=0.080$ ) were produced by various 4 - and 5 -variable combinations of surface sediment sorting with bottom water fluorescence, temperature, salinity and oxygen.

\section{Coherent distributions among the ampeliscids}

The Type 2 SIMPROF test at $p=0.05$ rejected the null hypothesis that the eight species were not associated with each other $(\pi=2.847, p=0.014, n=999)$. Three ampeliscid groups had coherent distributions (Type 3 SIMPROF test; Fig. 2): (1) A. macrocephala-Byblis spp.-H. laevis $(\pi=3.36, p=0.148, n=999)$; (2) Ampelisca sp. $-H$. tubicola $(\pi=0.49, p=0.481, n=999)$; and (3) Haploops sp.-H. sibirica-B. gaimardii $(\pi=3.19, p=0.744$, $n=999$ ). Within Group 1, the Index of Association (IA) was: 18.7 between A. macrocephala and Byblis spp., 17.5 between Byblis spp. and H. laevis and 17.2 between A. macrocephala and $H$. laevis. Within Group 2, IA $=13.4$ between Ampelisca sp. and H. tubicola. Within Group 3, IA =31.6 between Haploops sp. and $H$. sibirica, 21.1 between $H$. sibirica and B. gaimardii and 0 between Haploops sp. and B. gaimardii. Despite the dis-association of B. gaimardii with Haploops sp., B. gaimardii was more similar to Group 3 than to the other two groups.

\section{Identification effects}

The re-runs of SIMPROF on merged congeners (Online Resource 1) consistently produced a cohesive Group 1, consisting of A. macrocephala, Byblis spp. and H. laevis. Addition of the un-named congener to the named congener did not change this grouping. Conversely, Groups 2 and 3, which comprised the less frequently occurring species (Table 1), were more labile. Haploops tubicola and H. sibirica, which were indicated to be significantly different in distribution (Fig. 2) when all un-named species were considered to be

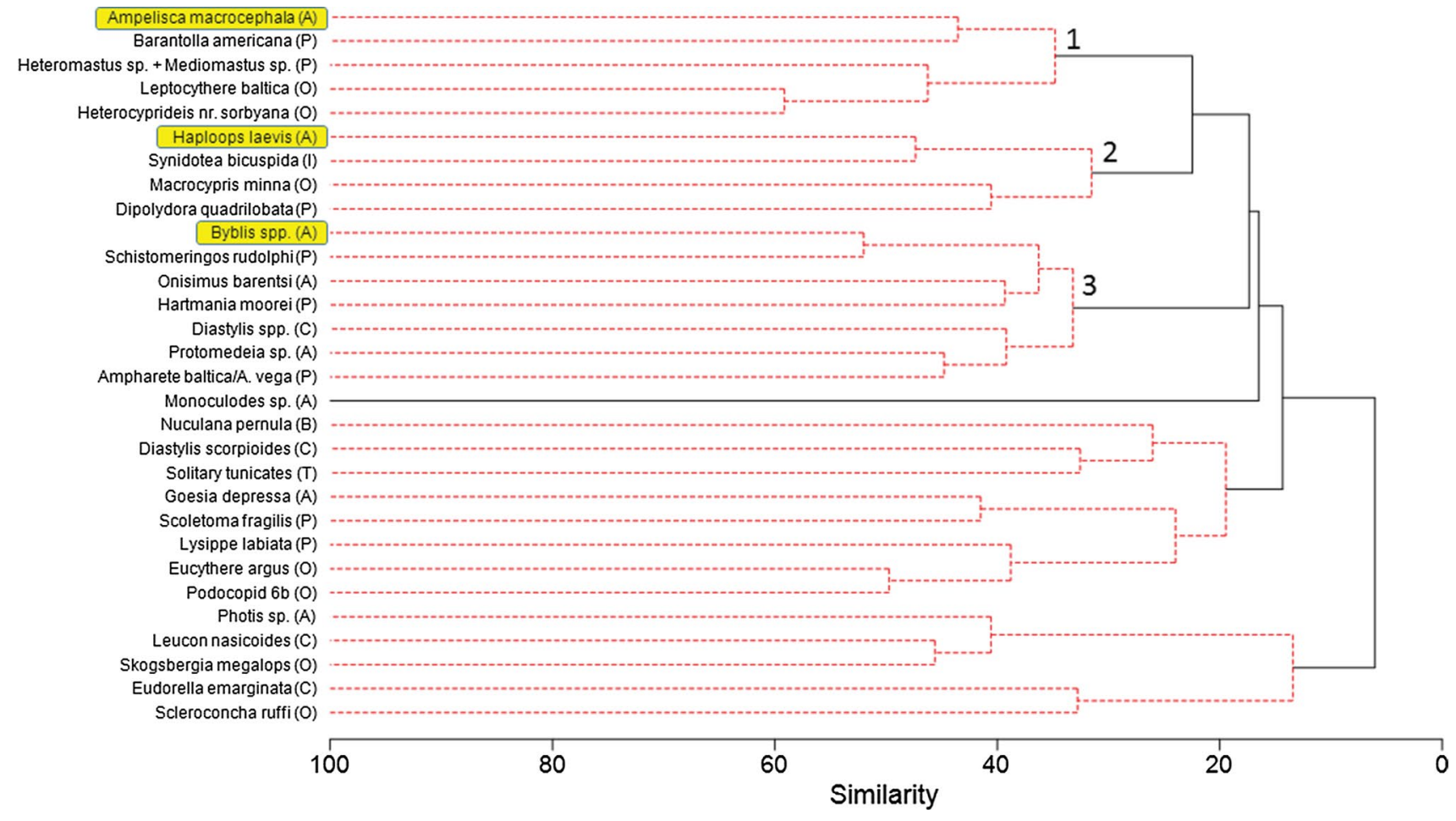

Fig. 3 Dendrogram of \% similarity of associations of 27 non-ampeliscid taxa with the three dominant ampeliscid species, A. macrocephala, H. laevis and Byblis spp. (highlighted). Within each of the groups linked by a dashed line, the null hypothesis that all pairs of species have the same association cannot be rejected (Type 3 SIM-
PROF test, $p=0.05$ ). Conversely, subgroupings linked by a solid line have statistical support. $\pi$ values at each of the numbered nodes are given in the text. Taxon codes: $A$ Amphipoda, $C$ Cumacea, $I$ Isopoda, $O$ Ostracoda, $P$ Polychaeta, $T$ Tunicata 


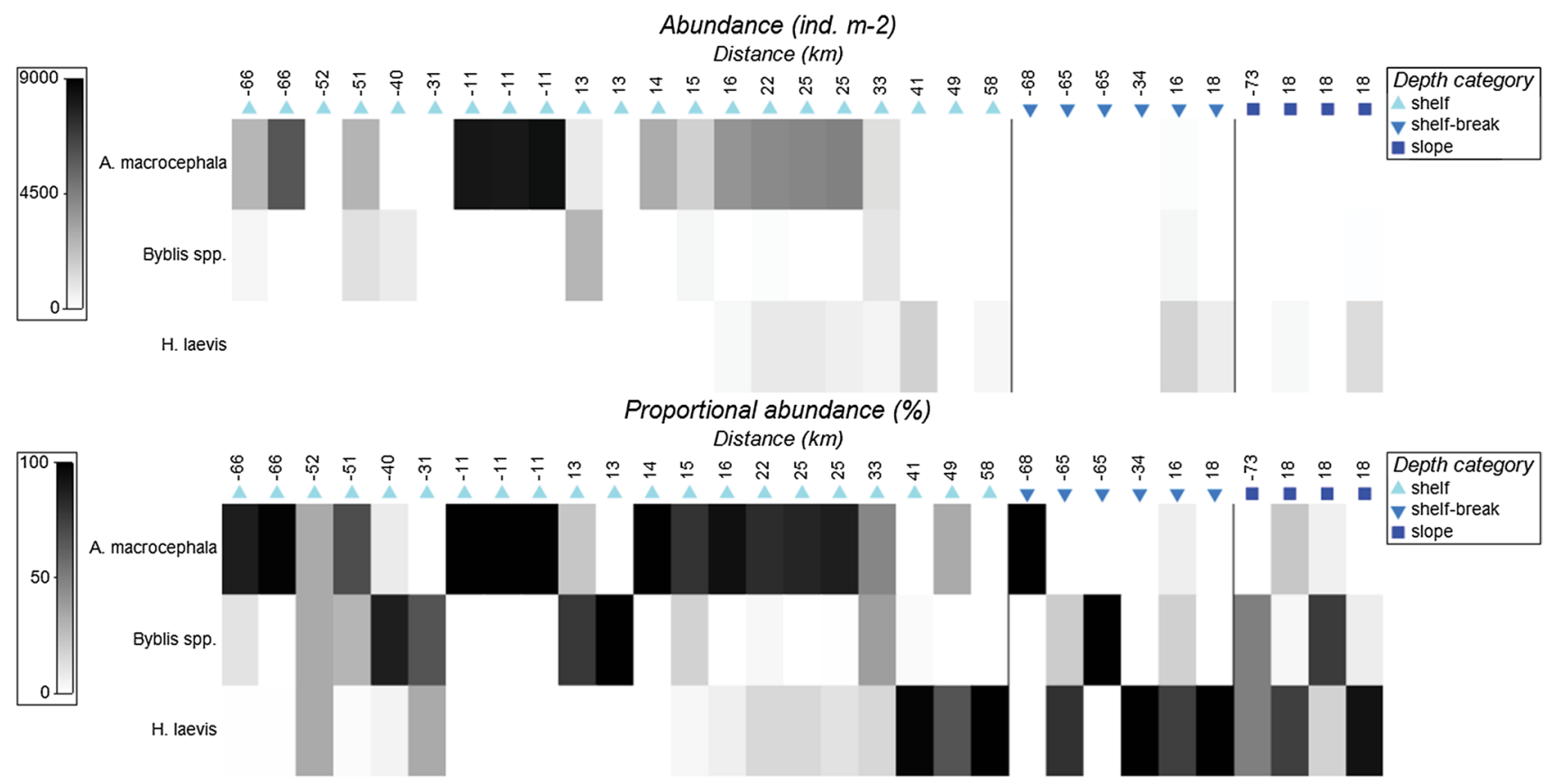

Fig. 4 Shade plots of abundance (no. ind. $\mathrm{m}^{-2}$ ) and proportional abundance (\%) of A. macrocephala, Byblis spp. and H. laevis along the shelf (12-50 m depth), shelf-break (59-74 m) and slope (80-

distinct, consistently grouped cohesively when Haploops sp. was merged with them, either fully or partially. The less frequently found $B$. gaimardii was affected by the merging of Haploops sp. with $H$. sibirica and $H$. tubicola by distancing its relationship with the others. Because of the potential for mis-identification to affect the congruence among the Group 2 and 3 species more than those in Group 1, further study was restricted to Group 1 species, which are the abundance dominants on the CBS.

\section{Coherent distributions of non-ampeliscids with the dominant ampeliscids}

Thirteen of the 27 non-ampeliscids were coherently distributed with the three dominant ampeliscids (Fig. 3). Congruent with A. macrocephala (Group $1 ; \pi=2.47, p=0.188$, $n=999$ ) were the polychaetes Barantolla americana and Heteromastus/Mediomastus as well as the ostracods Leptocythere baltica and Heterocyprideis nr. sorbyana. Congruent with H. laevis (Group 2; $\pi=1.00, p=0.962, n=999$ ) were the isopod Synidotea bicuspida, the ostracod Macrocypris minna and the polychaete Dipolydora quadrilobata. Congruent with Byblis spp. (Group 3; $\pi=1.18, p=0.751, n=999$ ) were the polychaetes Schistomeringos rudolphi, Hartmania moorei and Ampharete balticalA. vega, the amphipods Onisimus barentsi and Protomedeia sp. and the cumacean Diastylis spp. Characteristics of these associates are given in Online Resource 2. The other 14 non-ampeliscids showed
$119 \mathrm{~m}$ ) of eastern Cape Bathurst. Distances are km north (negative sign) and south (positive sign) of the tip of Cape Bathurst at $70.57^{\circ} \mathrm{N}$, $-128.02^{\circ} \mathrm{W}$

closer association with each other than with the dominant ampeliscids.

\section{Distribution patterns at Cape Bathurst}

Ampelisca macrocephala was the most frequent dominant at Cape Bathurst, occurring in 17 of the 21 shelf samples and ranging over 115 of the $124 \mathrm{~km}$ sampled (from $66 \mathrm{~km}$ north of the cape to $49 \mathrm{~km}$ south) (Fig. 4). Byblis spp. and $H$. laevis were found in 13 and 15 shelf samples, respectively (sometimes in small numbers) and co-occurred in 10 of these. They co-occurred with A. macrocephala in 10 and 12 of the 21 shelf samples, respectively, though in different locations from each other. All three species co-occurred in only 8 samples. Where A. macrocephala co-occurred with either of the other two species, it usually was proportionally more abundant. Its greatest abundance was at $11 \mathrm{~km}$ north of the cape (8467 ind. $\mathrm{m}^{-2}$ ) but it dominated the other two species from $66 \mathrm{~km}$ north to $33 \mathrm{~km}$ south. Byblis spp. was proportionally more abundant than A. macrocephala only in 3 samples. Its greatest abundance was from $51 \mathrm{~km}$ north to $33 \mathrm{~km}$ south of the cape with a peak ( 2592 ind. $\mathrm{m}^{-2}$ ) at $13 \mathrm{~km}$ south of the cape. Haploops laevis was absent or in low numbers close to the cape where A. macrocephala or Byblis spp. dominated but was proportionally more abundant further away when the other species dwindled out. Its abundance on the shelf peaked at $41 \mathrm{~km}$ south of the cape (1600 ind. $\mathrm{m}^{-2}$ ). 

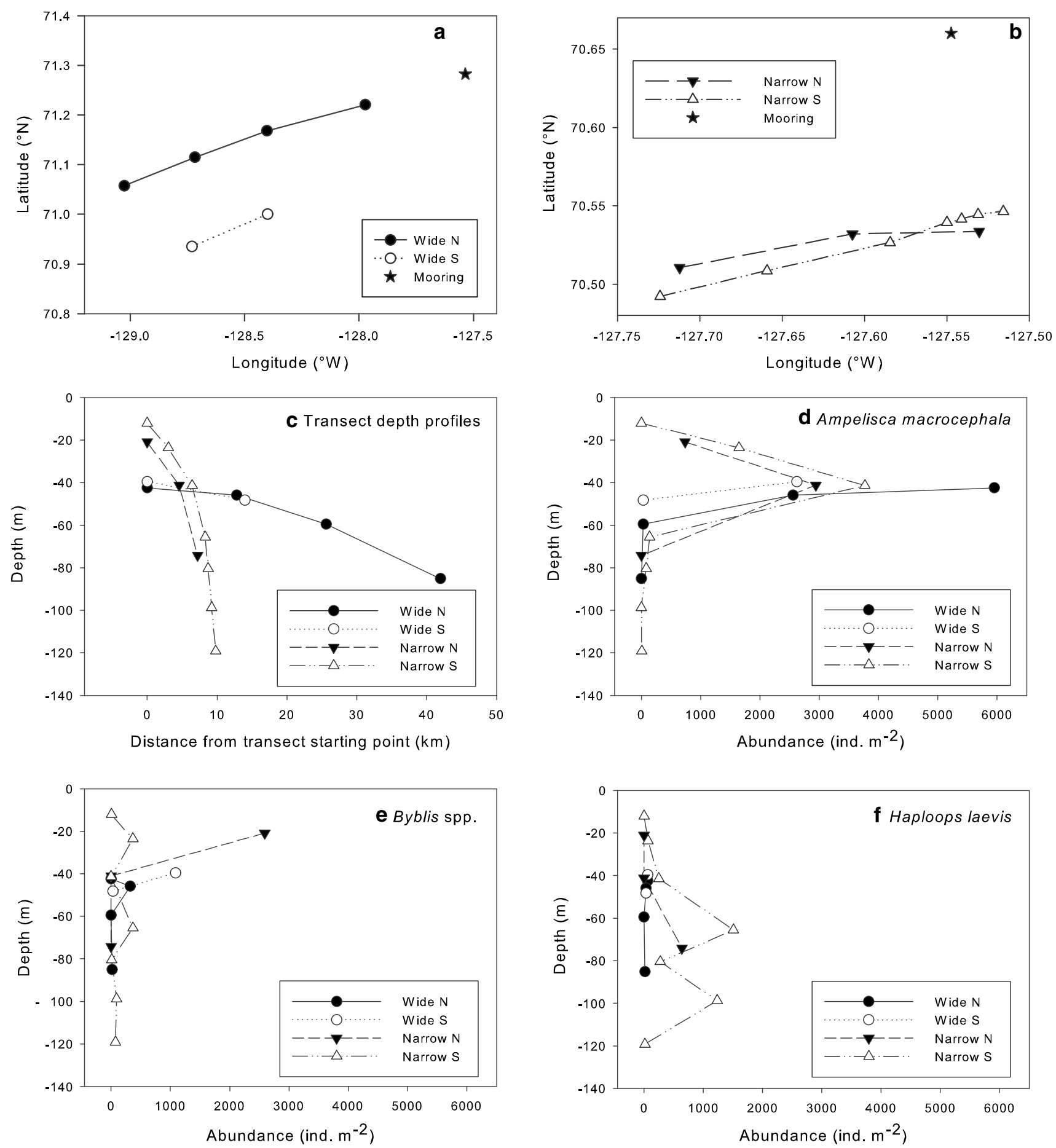

Fig. 5 Cross-shelf transects to the north and south of the tip of Cape Bathurst. a, b location of the transects relative to each other and to moorings set by Williams and Carmack (2008); c depth profiles of

the four transects; $\mathbf{d}-\mathbf{f}$ abundance profiles of A. macrocephala, Byblis spp. and H. laevis on the four transects

In the limited number of samples taken at the shelfbreak (6 samples from 59 to $74 \mathrm{~m}$ depth) and slope (4 samples from 80 to $119 \mathrm{~m}$ depth), H. laevis dominated in abundance more than either of the other two species. It was consistently present, even if in low numbers, from

$73 \mathrm{~km}$ north to $18 \mathrm{~km}$ south of the cape. Relative to the shelf, its peak abundances were comparably high on the shelf-break (1509 ind. $\mathrm{m}^{-2}$ ) and slope (1234 ind. $\mathrm{m}^{-2}$ ). The peaks were where the other two species were rare or absent, at 16 and $18 \mathrm{~km}$ south of the cape, respectively. 
Cross-shelf distribution patterns of the three dominant species are shown in Fig. 5. Ampelisca macrocephala was the dominant ampeliscid on the shelf in all four transects, with abundance peaks at $\sim 40 \mathrm{~m}$ (Fig. $5 \mathrm{~d}$ ). Abundance was highest on the Wide $\mathrm{N}$ transect (5952 ind. $\mathrm{m}^{-2}$ ) while on the other three transects, the maximum recorded abundance was 2624-3771 ind. $\mathrm{m}^{-2}$. Inshore, abundance was zero at $12 \mathrm{~m}$ but at $\sim 20 \mathrm{~m}$ it was well above zero (736 ind. $\mathrm{m}^{-2}$ at Narrow $\mathrm{N}$ and 1646 ind. $\mathrm{m}^{-2}$ at Narrow S; this depth not sampled on the Wide transects). Offshore, at $\sim 50 \mathrm{~m}$ and deeper, A. macrocephala was absent or in small numbers (32-137 ind. $\mathrm{m}^{-2}$ ). The pattern of abundance was strongly consistent among the four transects.

Byblis spp. co-occurred with A. macrocephala and showed similar peaks inshore, though it was not as strongly depth related as was A. macrocephala (Fig. 5e). Highest abundances were at 21-46 $\mathrm{m}\left(320-2592\right.$ ind. $\left.\mathrm{m}^{-2}\right)$ but on the Narrow $\mathrm{S}$ transect, abundance peaked again to 366 ind. $\mathrm{m}^{-2}$ at $66 \mathrm{~m}$. On the other transects, abundance was $0-91$ ind. $\mathrm{m}^{-2}$ at $>50 \mathrm{~m}$.

Haploops laevis was rare on the two wide shelf transects $\left(0-64\right.$ ind. $\left.\mathrm{m}^{-2}\right)$ but was found at higher densities on the narrow shelf transects $\left(0-1509\right.$ ind. $\left.\mathrm{m}^{-2}\right)$ (Fig. 5f). The highest abundance was at $66 \mathrm{~m}$ on the Narrow $\mathrm{S}$ transect and $74 \mathrm{~m}$ on the Narrow $\mathrm{N}$ transect (66 m not sampled). A second abundance peak was found on the Narrow $\mathrm{S}$ transect at $\left.91 \mathrm{~m} \mathrm{(1234} \mathrm{ind.} \mathrm{m}^{-2}\right)$. Small numbers $\left(17\right.$ ind. $\left.\mathrm{m}^{-2}\right)$ were found deeper at the Narrow $\mathrm{S}$ transect end-point at $119 \mathrm{~m}$. These deeper depths were not sampled on the other transects.

\section{Discussion}

\section{Ampeliscid biogeography and species composition}

The presence of A. macrocephala, B. gaimardii, H. laevis, $H$. tubicola and $H$. sibirica on the CBS can be explained by its oceanography, which includes three main water layers: the shallow Polar Mixed Layer which is dominated by the large Mackenzie River, underlain by the warmer, nutrient rich, and saltier (but freshened) Pacific water beginning at 60-100 $\mathrm{m}$ and below that, at $>200 \mathrm{~m}$, the warm and salty Atlantic water (Carmack et al. 1989; Carmack and Macdonald 2002; Carmack et al. 2004; Melling et al. 2012). All the CBS species ranged into the riverine coastal domaine ( $<20 \mathrm{~m}$; Carmack et al. 2016), suggesting that they could tolerate periodic influence of the Mackenzie River (Fig. 1). All species also occurred on the shelf and showed abundance peaks around Cape Bathurst, indicating that they were influenced by the nutrient-rich Pacific water. Ampelisca macrocephala, $B$. gaimardii and $H$. laevis dominate in Pacific waters of the adjacent Bering and/or Chukchi Seas which flow into the CBS (Coyle and Highsmith 1989; Highsmith and Coyle 1990, 1991; Feder et al. 1994; Carmack and Macdonald 2002). Haploops tubicola and H. sibirica were found well into the Atlantic layer in Amundsen Gulf (396-514 m) (Table 1). Haploops tubicola has the most wide-ranging biogeography of the CBS ampeliscids, both latitudinally and longitudinally. It is known as far south as California on the NE Pacific coast and to the Iberian Peninsula in the NW Atlantic (Dickinson 1983; Dauvin et al. 2012). Haploops is considered to be a deeper living genus than Ampelisca (Bellan-Santini and Dauvin 1997), although bathymetric overlap is considerable (Dauvin et al. 2012). The rarest species on the CBS, $H$. sibirica, occurs widely in the Russian Arctic and NW Pacific south to the Sea of Japan (Gurjanova 1951). All the ampeliscids were collected shallower than the maximum depth known for the species. This may reflect the Beaufort environment, where productivity is highly seasonal and interannually variable (Carmack and Macdonald 2002; Arrigo and van Dijken 2004). Given these wide distributions, these species will likely be found in other parts of the Canadian Arctic and under the right conditions may form dense beds.

The three un-named species, Ampelisca sp., Byblis spp. and Haploops sp., may be new to science or unrecognized species complexes. Five species of Ampelisca, six species of Byblis and four species of Haploops are known in the Bering, Chukchi and/or Beaufort Seas (Dickinson 1982, 1983; Coyle and Highsmith 1989). Only the most abundant have been previously distinguished for ecological studies there, because species are inseparable if they are damaged or young (Highsmith and Coyle 1991; Coyle and Highsmith 1994). In this study, great care was given to species identification but preservation prevented the use of additional distinguishing characters such as living color, behavior and genetic material. Small individuals of the five nominal species lacking the diagnostic characters of adults could have also fallen within these un-named categories, although misidentification of the genus was unlikely as generic characteristics were recognizable at any size.

\section{Environmental relationships}

The BEST analysis showed that site similarities based on environmental versus individual species distributions had very low correlation and that different combinations of water and sediment variables produced nearly the same correlations. Sampling variables (date, sampler and sample size) were never part of the 5-variable combinations that produced the highest correlations. This indicates that sampling bias was low. Many of the environmental variables transition with distance from land, but this is not entirely related to depth because of offshore rises and the inshore effect of the Mackenzie River on the western part of the CBS. Thus, fluorescence is highest close to the delta and sediment $\delta^{13} \mathrm{C}$ 
transitions from land-derived organic matter near the delta to planktonic offshore (Conlan et al. 2008, 2013). However, depth may embrace a variety of spatially and temporally varying variables that collectively influence the benthos. Depth was also found to be the best correlate for benthic invertebrate distributions in the Chukchi Sea (Schonberg et al. 2014) and demersal fish distributions on the CBS because of the layered water masses (Majewski et al. 2017).

All three ampeliscid genera were mostly concentrated in cold, high salinity water, although H. laevis, Haploops sp. and B. gaimardii were also found close to the Mackenzie Delta where the bottom water was brackish (Fig. 1 and Table 1). Warm, low salinity surface water from the Mackenzie River can spread eastwards along the coast as far as the base of Cape Bathurst (Carmack et al. 1989). The deeper living species of Haploops spanned a greater temperature range than the species of Ampelisca because they penetrated into the slightly warmer $\left(>0{ }^{\circ} \mathrm{C}\right)$ Atlantic water at $>200 \mathrm{~m}$ depth. All species did not occur in bottom water any warmer than $0.41{ }^{\circ} \mathrm{C}$, however.

Besides fresh water and heat, the Mackenzie River brings in massive amounts of sediment (127 Mt a ${ }^{-1}$; Macdonald et al. 1998), far exceeding that of other Arctic rivers (Carmack and Macdonald 2002). This produces a dynamically moving plume of predominantly clay and silt settling close to the Mackenzie Delta that moves with the winds and currents and also re-suspends (Carmack and Macdonald 2002). Coastal erosion contributes an added $\sim 5 \%$ of sediment (Carmack and Macdonald 2002). All ampeliscid species were found in sediments with high clay-silt content. Sediment characteristics are important to ampeliscids as they supply substrate for tube building. The ampeliscids spend most of their lives in self-built tubes, where they position themselves ventral side up at the tube mouth for feeding (Enequist 1949). They glue the sediment particles with "amphipod silk" secreted from glands in pereopods 3 and 4 . Ampelisca macrocephala and $H$. tubicola build tubes most readily in clay or clay mixed with fine sand. Clay increases the tube's firmness but pure clay prevents the threads from taking hold while threads constructed in pure sand cannot be stretched (Enequist 1949). Sediment maps for the CBS show the prevalence of silt close to the Mackenzie River inflow and in the Mackenzie Trough with a higher proportion of sand on the western half of the CBS, especially around Cape Bathurst where currents are high (Jerosch 2013). High sand proportions also occur where former beaches and old drilling islands are now submerged (Croasdale and Marcellus 1978). The coarser sediment, along with greater distance from the influence of the Mackenzie River, may influence ampeliscid settlement. At least some ampeliscids also settle preferentially where occupied or empty ampeliscid tubes are present (Dauvin and Bellan-Santini 1990).
The low correlations of environmental variables with the ampeliscid distributions could have been due to several factors: that the environmental variables measured were not those that were highly influential; the environmental measurements were only single snapshots at the time of sampling and did not supply sufficient information on conditions encountered throughout the species' lives; that missing environmental data lowered the correlations; and that congeners broadly overlapped in environmental requirements. Carmack and Macdonald (2002) suggest that the timing of the seasonal cycle on the CBS (e.g., Mackenzie River freshet, sea ice breakup and freeze-up) is more important to biota than individual quantifiable measures. Other seasonal factors that may influence ampeliscid distributions are the effects of ice scour over the shelf, the winter-spring flaw lead-polynya system, spring ice algal production, late spring and autumn phytoplankton blooms and upwelling during the summerautumn open water season.

Seafloor disturbance by ice scour will impact ampeliscids to $50 \mathrm{~m}$ depth and most intensively where the land-fast ice meets the moving pack ice at 10-20 m (Gilbert and Pedersen 1987; Lewis and Blasco 1990; Héquette et al. 1995; Myers et al. 1996; Carmack and Macdonald 2002). This may explain why the abundance of $A$. macrocephala peaks at 40-50 $\mathrm{m}$ and declines inshore, as observed in the four transects near Cape Bathurst (although Byblis spp. peaked at shallower depths in some transects). Ice scour can have a positive influence on biodiversity, though, by creating a mosaic of recolonizing benthos (Conlan and Kvitek 2005).

The winter flaw lead develops over the CBS between the land-fast ice and the moving pack ice mid-shelf, approximately seaward of the $20 \mathrm{~m}$ isobath and runs from Mackenzie Trough to Amundsen Gulf (Carmack and Macdonald 2002; Barber and Hanesiak 2004). It opens and closes over the winter, with a maximum width of about $70 \mathrm{~km}$ to the $30 \mathrm{~m}$ isobath (Williams et al. 2008). An extension of the flaw lead at the mouth of Amundsen Gulf is a polynya, a consequence of wind-driven upwelling near the shelf-break (Lukovich and Barber 2005; Williams and Carmack 2008). This flaw lead-polynya system enables a spring phytoplankton bloom, although the timing and persistence of this system are variable (Arrigo and van Dijken 2004; Simpson et al. 2013a, b). Early phytoplankton production should benefit ampeliscids that were found in relatively high numbers on the shelf between Kugmallit Valley and Cape Bathurst (H. tubicola, B. gaimardii and Ampelisca sp.) and also on the shelf-edge to the north and east of Cape Bathurst (all species). A carbon flow model in the polynya indicated that $60 \%$ of the benthic carbon demand was supplied by sinking carbon in the flaw lead-polynya system in spring-summer 2008 (Forest et al. 2011). Ice algae can also be an important spring carbon source for the benthos in Amundsen Gulf (Renaud et al. 
2007b). Polynyas can also influence the benthos as a result of brine injection at the flaw lead and polynya edge, either by brine flow over the benthos or by baroclinic currents mixing the surface layer to as deep as 40-50 $\mathrm{m}$ (Grebmeier and Cooper 1995; Carmack and Macdonald 2002).

Late-spring pelagic production offshore after sea ice retreat is also a carbon source to the benthos on the CBS. Later in autumn, a second but smaller phytoplankton bloom induced by nutrient mixing spreads widely over the CBS and should benefit the ampeliscids (Arrigo and van Dijken 2004). While winter primary production is low (Simpson et al. 2013a), some species in the Arctic may grow and reproduce primarily in winter (Demchenko et al. 2016).

The elevated abundances of each ampeliscid species around Cape Bathurst point to upwelling as an important influence. Wind-driven upwelling draws up larger and older copepod stages which have descended into Amundsen Gulf to overwinter (Walkusz et al. 2012, 2013), and these copepods may be preyed upon by the larger A. macrocephala. Whole zooplankton abundance and biomass at Cape Bathurst can be $2-3 \times$ that on the shelf to the west. Sampling zooplankton close to the Wide and Narrow shelf transects after 7 weeks of upwelling favorable winds, Walkusz et al. (2012) found $279 \pm 307$ ind. $\mathrm{m}^{-3}$ (dry mass $0.068 \pm 0.043 \mathrm{~g} \mathrm{~m}^{-3}$ ) close to the Wide Shelf transect and $368 \pm 520$ ind. $\mathrm{m}^{-3}$ $\left(0.066 \pm 0.049 \mathrm{~g} \mathrm{~m}^{-3}\right)$ close to the Narrow Shelf transect at Cape Bathurst. By comparison, in Kugmallit Bay $(\sim 160 \mathrm{~km}$ west of Cape Bathurst), density and biomass were $130 \pm 114$ ind. $\mathrm{m}^{-3}\left(0.026 \pm 0.012 \mathrm{~g} \mathrm{~m}^{-3}\right)$. During summer open water on the CBS (May-October), upwelling favorable winds dominate (Ben Mustapha et al. 2010), which should lead to a reliable and frequent suspended food supply at, and to the west of Cape Bathurst.

Along with a draw-up of zooplankton, wind-driven upwelling also brings nutrient-rich water to the surface which spreads northwards and westwards over the shelf of the CBS, following the divergence of the isobaths (Arrigo and van Dijken 2004; Williams and Carmack 2008). This fuels phytoplankton production, an essential food resource for all the ampeliscids (Online Resource 3). This is primarily in the form of diatoms, which are considerably more productive off Cape Bathurst than elsewhere on the CBS (128.7 g $\mathrm{C} \mathrm{m}^{-2}$ year $^{-1}$ at mooring CA6 in 2003-2004 compared to $14.5 \mathrm{~g} \mathrm{C} \mathrm{m}^{-2}$ year $^{-1}$ in Mackenzie Trough and $2.8 \mathrm{~g} \mathrm{C} \mathrm{m}^{-2}$ year ${ }^{-1}$ mid-slope; Sampei et al. 2011). This elevated diatom production reaches the benthos, as evidenced by increased fucoxanthin in the sediment, a diatom marker, and benthic carbon demand is substantially higher at Cape Bathurst than elsewhere on the CBS (Renaud et al. 2007a; Morata et al. 2008).

Upwelling (and downwelling) can create high currents, especially on steep slopes. Water flow of up to $70 \mathrm{~cm} \mathrm{~s}^{-1}$ was recorded by the ADCP moored at $13 \mathrm{~m}$ depth at CA6 over Sep. 2002-Sep. 2003 (Williams and Carmack 2008) (Fig. 5). By comparison, at mooring CA5, where the shelf is wider and the slope is more gradual, flows did not exceed $30 \mathrm{~cm} \mathrm{~s}^{-1}$ over the same period and at comparative depth. The matching pattern of ampeliscid abundance (highest at the eastern edge of Cape Bathurst and spreading westward) suggests a strong effect of upwelling events with A. macrocephala tolerating high currents and concentrating where upwelling effects are greatest. Along the Cape Bathurst eastern shore, the dominance was A. macrocephala $>$ Byblis spp. $>$ H. laevis at $<50 \mathrm{~m}$ depth. Feder et al. (1994) found a similar depth relationship in the adjacent Chukchi Sea. At $>50 \mathrm{~m}$, the dominance reversed, with the smaller H. laevis dominating, indicating a greater capacity to live in a less food-rich environment with potentially smaller particle size. The other five species also peaked in abundance at Cape Bathurst but were less abundant or less frequently found there.

Mackenzie Trough and Kugmallit Valley likely also influence ampeliscid distributions as they are conduits for upwelling, caused by wind in summer and ice motion in winter and also for downwelling of near-freezing salty water from the flaw-lead (Carmack and Kulikov 1998; Williams et al. 2006, 2008). In Mackenzie Trough, upwelling can draw water from the nutrient maximum 100-200 m deep, affecting the eastern side of the trough (Williams et al. 2006). Haploops laevis, Haploops sp. and H. tubicola showed some abundance increases there, but the absence of the larger Ampelisca macrocephala shows that upwelling there is not as influential on the benthos as at Cape Bathurst. In Kugmallit Valley, upwelling draws water cross-shelf and to the east (Williams et al. 2008). Upwelling from Mackenzie Trough and Cape Bathurst can also reach this area (Williams and Carmack 2008; Williams et al. 2008; Walkusz et al. 2012). The presence of A. macrocephala along the eastern edge of the valley, but near absence to the west, and sustained high numbers on the shelf further east of the valley suggests that adequate resources are reaching this large ampeliscid there. These resources may not have to be consistently high. Temperate A. macrocephala can withstand starvation for at least 5 months in aquaria (Kanneworff 1965) and its Arctic congener, A. eschrichtii, can starve through the summer when phytoplankton are largely out of reach, growing and reproducing in winter when storms mix phytoplankton to within reach (Durkina et al. 2018).

\section{Biological differences among the ampeliscids}

The ampeliscid distributions can also be explained by differences in feeding morphology and behavior. Ampeliscids consume suspended and deposited particles (diatoms, detritus and small organisms) filtered and combed through the setae and spines on their antennae and legs (Online Resource 
Table 2 Comparison of the life history and stable isotope composition of Ampelisca macrocephala and Byblis gaimardii in the Bering and Chukchi Seas

\begin{tabular}{lll}
\hline Comparator & Ampelisca macrocephala & Byblis gaimardii \\
\hline Annual growth (mm) & $4-5$ & 6 \\
Max. body length (mm) & 33 & $\sim 23$ to 25 \\
Age at female maturation (years) & $4-5$ & 2.5 \\
Number of possible broods & $2-3$ & $3-4$ \\
Max. brood size & 58 & 30 \\
Hatchling length (mm) & 5 & 4 \\
Carbon requirement to reach 20-24 mm length $\left(\mathrm{g} \mathrm{m}^{-2}\right.$ year $^{-1}$ ) & 221 & 110 \\
Stable isotope composition (under the relatively unproductive Alaska & $\delta^{15} \mathrm{~N} 13.99 \pm 0.41$ & $\delta^{15} \mathrm{~N} 10.93 \pm 0.97$ \\
$\quad$ Coastal Water in the southern Chukchi Sea) $($ mean $\pm S D, n=3)$ & $\delta^{13} \mathrm{C}-18.92 \pm 0.39$ & $\delta^{13} \mathrm{C}-22.69 \pm 0.67$ \\
Stable isotope composition (under the highly productive Anadyr & $\delta^{15} \mathrm{~N} 8.10 \pm 0.58$ & $\delta^{15} \mathrm{~N} 8.08 \pm 0.48$ \\
$\quad$ Water) (mean $\pm S D, n=6)$ & $\delta^{13} \mathrm{C}-20.00 \pm 0.35$ & $\delta^{13} \mathrm{C}-20.68 \pm 0.42$ \\
\hline
\end{tabular}

Sources Highsmith and Coyle (1991) for life history and Iken et al. (2010) for stable isotope composition. Data were based on specimens that were dominated by these species but could have had congeners mixed with them

3). Studies on three species common to the CBS (European H. tubicola and A. macrocephala and Chukchi Sea $B$. gaimardii and A. macrocephala) indicate behavioral differences. Haploops tubicola is an obligate suspension feeder on diatoms, detritus and microorganisms; it does not capture zooplankton, at least in laboratory experiments (Enequist 1949; Rigolet et al. 2011). Its antennal net is fine meshed and sticky and it can feed in turbid conditions (Rigolet et al. 2011). Its morphology reflects this with dense setation along the body, mouthparts and legs. Its tube is elevated above the sediment to aid suspended particle capture and it rarely leaves its tube (Enequist 1949; Dauvin and Zouhiri 1996).

By comparison, in B. gaimardii and A. macrocephala, the antennal mesh is coarser than in H. tubicola and nonsticky. Their tubes are flush with the sediment where they can sweep the surface of deposited material to supplement suspension feeding. They also prey on small crustaceans and they easily leave their tubes and swim into the water column (Enequist 1949; Kanneworff 1965; Mills 1967; Highsmith and Coyle 1990, 1991; Dauvin and Zouhiri 1996; Rigolet et al. 2011). They have four eyes instead of two and the pereopod 7 basis is posteriorly winged, features that may assist in swimming, prey location and current funnelling.

Comparing B. gaimardii to A. macrocephala in the Bering Sea (Table 2), B. gaimardii is able to dominate over the larger A. macrocephala when carbon flux is lower because it has about half the carbon demand and a shorter generation time (Highsmith and Coyle 1991; Coyle and Highsmith 1994). While both genera consume phytoplankton and ice algae when available, A. macrocephala can shift to a greater animal diet when particulate matter is sparse. Byblis gaimardii is able to sustain itself in both high and low particulate waters (Iken et al. 2010; Tu et al. 2015; McTigue and Dunton 2017). A comparison of the sediment $\delta^{13} \mathrm{C}$ range for $A$. macrocephala and B. gaimardii on the CBS (Table 1) with the tissue and sediment levels in the Chukchi Sea (Table 2; Grebmeier et al. 2006a) indicates that these species may have different carbon sources in the two areas, with the CBS being more land based due to the high sediment load supplied by the Mackenzie River.

These biological differences are reflected in the broad distribution patterns found on the CBS (Fig. 1): concentration of the high resource-demanding A. macrocephala in the most intense upwelling areas but declining abundance further away, compared to broader distributions of the less demanding $B$. gaimardii, and the presence of the fine particulate-feeding $H$. tubicola in the deep parts of Amundsen Gulf. For the other two nominal species, H. laevis and $H$. sibirica, there is much less biological information. Haploops laevis has a shorter tube than $H$. tubicola because its antennae are shorter (Kanneworff 1966). It is also larger than $H$. tubicola, suggesting greater resource requirements which are met in upwelling areas but not on the slope. Haploops tubicola has been found in dense aggregations on European coasts, suggesting that on the CBS it may be out-competed by $H$. laevis. Haploops sibirica is morphologically similar to H. laevis (Kanneworff 1966), which suggests a similar biology. The two species overlap on the shelf of the CBS but $H$. sibirica was found in Amundsen Gulf while H. laevis was never found so deep.

\section{Coherent distributions among the ampeliscids}

The SIMPROF analysis demonstrated that species in the same genus did not generally have similar distributions. Differing morphologies, feeding and swimming behaviors and differences in size, carbon demand, reproductive potential, space competition and predation rates will all enable cohabitation (Coyle and Highsmith 1994). The low similarities of 
the Index of Association may be due to their relatively low frequency of occurrence (5-30\% of the sites, depending on the species). While some species were widespread on the CBS (Haploops sp. and H. tubicola), others were primarily in the Cape Bathurst area (A. macrocephala, Byblis spp. and $H$. laevis). Although effort was made to cover the shelf and slope adequately over the 2002-2009 sampling period, ship operations were directed by differing scientific aims, resulting in an under-sampling of the Cape Bathurst area and more intensive sampling of the central and western part of the shelf, which was not an ampeliscid-rich area. The shelf also received more sampling effort than the slope. A more intensive sampling of the eastern part of the shelf would have more clearly delineated the extent of upwelling effects on the ampeliscids, as noted in Conlan et al. (2013). More intensive sampling of the slope may have targeted the deeper living species of Haploops, although these also occurred on the shelf.

\section{Identification effects}

The investigation of how potential mis-identifications might affect the results showed that the Group 1 species A. macrocephala, Byblis spp. and H. laevis formed a strongly cohesive group that held when mis-identifications were introduced (Online Resource 1). These species were the most frequently found and their distributions overlapped, with the greatest proportion of their abundance concentrating at Cape Bathurst. Introduction of mis-identifications to Group 2 (Ampelisca sp. and H. tubicola) and Group 3 (Haploops sp., $H$. sibirica and B. gaimardii) caused $H$. tubicola and $H$. sibirica to appear more cohesive in distribution and $B$. gaimardii to be more distinctive. These were the less frequent species and consequently, merging of congeners added additional sites to their distributions rather than simply reinforcing their already known distributions. For example, Haploops sp. occurred in nearly $3 \mathrm{x}$ as many sites as $\mathrm{H}$. sibirica (Fig. 1, Table 1) and so, when merged, effectively boosted the frequency of $H$. sibirica to occurring in as many sites as H. tubicola.

\section{Coherent distributions of non-ampeliscids with the dominant ampeliscids}

Many of the 13 species coherently distributed with the dominant three ampeliscids (Fig. 3, Online Resource 2) were small crustaceans (amphipods, podocopid ostracods, cumaceans or isopods) or polychaetes (five families) that could have been responding independently to similar environmental conditions as the ampeliscids or were interacting with them. Many of these associates were surface mobile, tube dwelling or burrowing deposit feeders, suggesting that high deposition of labile, phytoplankton-derived organic matter at Cape Bathurst (rather than refractory, land-derived carbon) was the prime driver. Biological interactions may also be occurring, though. Those organisms identified as predators or deposit feeders may affect ampeliscid distributions by preying on or disturbing the adults or small juveniles. They may also re-work the sediment, bringing resources to the surface for the ampeliscids. In turn, they may be positively influenced by changes effected by the ampeliscids to the surface sediment grain size, $\mathrm{C}$ and $\mathrm{N}$ content, benthic primary production, flow mechanics, sediment stability and availability of refuges from predation (Mills 1967; Rigolet et al. 2014a, b). The ampeliscid tubes also provide attachment sites to elevate into the water column. Various tube-living amphipods associate with ampeliscid beds in this way (Wildish 1984; Rigolet et al. 2011, 2012; Myers et al. 2012; Mironov 2013; Brower et al. 2017).

There are documented examples of apparent facilitation and exclusion in ampeliscid beds. Ampelisca abdita in Raritan Bay (New Jersey) is thought to facilitate the bivalve Mercenaria mercenaria by providing a low-current, low-silt and solid settlement site on its tubes for the bivalve larvae as well as deterring the crab and oyster drill predators of the bivalves (Mackenzie et al. 2006). Haploops nirae off the coast of Brittany is thought to facilitate diatom attachment and growth on its tubes which then provides opportunities for grazers and deposit feeders (Rigolet et al. 2014a, b; Dubois et al. 2015). Ampelisca macrocephala in the Bering Sea consumes juveniles of the northern sand dollar, Echinarachnius parma, thereby excluding a potential space competitor (Highsmith and Coyle 1991). In these tube mats, species composition is significantly different from that outside the mat, indicating both facilitation and exclusion.

\section{Ampeliscids and gray whales}

Ampelisca macrocephala reached a maximal abundance of 8467 ind. $\mathrm{m}^{-2}$ at Cape Bathurst, a value that is slightly greater than as reported in Conlan et al. (2013) which was based on fewer samples. This value exceeds by $3 \times$ the maximum abundance attained by the more frequently occurring Byblis spp. and by $5 \times$ that by $H$. laevis. Ampelisca macrocephala is the most abundant ampeliscid in the Bering and Chukchi Seas as well, where it also dominates in biomass and production (Highsmith and Coyle 1992; Coyle and Highsmith 1994). This species is a better space competitor than other Arctic species but requires a low predation rate and high fluxes of organic matter (Coyle and Highsmith 1994). It is the prime prey of eastern Pacific gray whales here (Coyle and Highsmith 1994); A. eschrichti supports a smaller population of western Pacific gray whales (Demchenko et al. 2016). Seafloor disturbance by feeding gray whales leaves $A$. macrocephala vulnerable to attack by scavenging benthic amphipods (Oliver and Slattery 1985) as 
well as surface and diving seabirds (Grebmeier and Harrison 1992). However, gray whale feeding also creates a mosaic of seafloor depressions which are colonized by different species, resulting in an overall higher biodiversity (Oliver et al. 1984; Oliver and Slattery 1985). Such an effect of natural disturbance on macrofauna is paralleled by the effects of seafloor excavations created by ice scour (Conlan and Kvitek 2005) and gas venting (Dubois et al. 2015).

In the Chukchi Sea, gray whales target areas where amphipod densities are $>85 \mathrm{~m}^{-2}$ (Brower et al. 2017). Most parts of the CBS meet this density criterion for ampeliscids alone (Fig. 1). The widespread soft sediment on the CBS (Jerosch 2013) would be suitable for benthic feeding gray whales which suck the sediment and strain the contents through their baleen (Highsmith et al. 2007). Since gray whales also consume a wide variety of other benthic, epibenthic and pelagic organisms (Highsmith et al. 2007; Budnikova and Blokhin 2012), other areas of the CBS that are less ampeliscid rich but have high densities of other taxa (Conlan et al. 2008) may also be suitable. Elevated macrofaunal biomass is estimated to cover $4550 \mathrm{~km}^{2}$ of the CBS at and to the west of Cape Bathurst (Conlan et al. 2013). Elevated pelagic resources occur at times of wind-driven upwelling which attract bowhead whales (Walkusz et al. 2012) but gray whales have also been seen there (Conlan et al. 2013).

Dense ampeliscid beds exist in other parts of the world also and the Atlantic beds may have been foraged previously by gray whales before the whale's Atlantic population was driven to extinction by whaling (Jones and Swartz 2009). Some ampeliscid densities in the Atlantic surpass 150,000 ind. $\mathrm{m}^{-2}$ (Rigolet et al. 2012; Conlan et al. 2013). There have been recent sightings of two different Pacific gray whales in the Atlantic, one seen off Israel and then off Spain in 2010 and another off Namibia in 2013 (Zimmer 2015; Schiffman 2016). These were presumed to have accessed the Atlantic through the Arctic. If regime shifts occur in the Bering and Chukchi Seas, as has been documented previously (Grebmeier et al. 2006b; Bluhm and Gradinger 2008), and ice-free periods on the CBS are extensive, the CBS may be more frequently visited than previously documented. Whether this is happening is not known, however, as offshore whale monitoring and industrial activity in the CBS, which would have increased the chance of sighting gray whales, were discontinued after 2010 (Lois Harwood, pers. comm., 13 July 2018). Changes to gray whale movements will depend on how climate forcing and disturbance influence the gray whales as well as the productivity of the ampeliscids and other prey (Moore et al. 2003; Grebmeier et al. 2006; Tremblay et al. 2011; Kędra et al. 2015; Burnham and Duffus 2016; Villegas-Amtmann et al. 2017).

\section{Future monitoring}

With the many physical and chemical changes to the CBS that can be initiated by climate forcing will come biotic changes in every habitat at every trophic level (Carmack and Macdonald 2002; Barber et al. 2008; Wassmann et al. 2011; Kędra et al. 2015). Arctic ampeliscids, especially the large A. macrocephala, have slow growth rates and long generation times and they may be unable to recover quickly from biological or physical changes (Coyle et al. 2007). Arctic $A$. macrocephala appear to be specially adapted to a high latitude environment by having a larger genome than any other Arctic amphipod that has been investigated so far (Rees et al. 2007). Although most of the species in this study, including A. macrocephala, have populations at lower latitudes, suggesting potential environmental resilience, there are no data on how similar they are genetically or physiologically. This study showed that none of the CBS species occurred in water warmer than $0.41^{\circ} \mathrm{C}$, suggesting that the CBS species may be intolerant of warming.

Ampeliscids support a variety of upper trophic level predators because of their tendency to live in aggregations, be highly productive, and be available to both benthic and pelagic consumers because they swarm to mate. The composition, distribution and seasonality of these ampeliscid populations will be worth monitoring as their environmental sensitivities, ecological interactions, physiological tolerances, life histories and linkages to large predators are becoming better understood (Moore et al. 2003; Renaud et al. 2015). Impetus toward pan-Arctic biodiversity monitoring is growing and Cape Bathurst has been designated as a desired benthic monitoring area for benthic changes in the CBS (Gill et al. 2011). The Inuvialuit and the Canadian government co-manage the natural resources of the CBS. There are six permanent communities on the shores of the CBS which make use of the local marine mammals, birds and fish for sustenance (Ayles et al. 2016).

This study has demonstrated that at least eight species of ampeliscids span the CBS yet each is distributed differently. They are clearly dependent on events in the water column (upwelling) and also benthic availability of resources and sediment particulates for tube building. Changes to any one species could signal underlying environmental changes that may not be evident through physico-chemical monitoring. Of particular focus should be A. macrocephala because of its dependence on high productivity and $H$. sibirica because it is primarily Arctic in distribution. Long-term changes to H. tubicola and B. gaimardii, with temperate ranges, high generation times and ability to capture small particulates may indicate environmental change also. All the nominal species are known from other parts of the Arctic and range 
shifts have been reported from the warming Barents Sea (Lyubina et al. 2014). Other polar and temperate ampeliscid beds have been or are beginning to be monitored long term (Poggiale and Dauvin 2001; Ehrhold et al. 2006; Coyle et al. 2007; Burnham and Duffus 2016; Demchenko et al. 2016), giving trend data that may predict changes on the CBS. The information that is now available on the CBS and neighboring Bering and Chukchi ampeliscids, their importance to upper trophic level predators, and their biological differences and environmental sensitivities outlined in this and other studies all point to these amphipods as being valuable environmental monitors.

Acknowledgements This research was funded by the Canadian Museum of Nature (CMN), the Department of Fisheries and Oceans (DFO-led by Don Cobb) and the Geological Survey of Canada (GSC-led by Steve Blasco) for the Nahidik (Northern Coastal Marine Studies) Program and the Natural Sciences and Engineering Research Council for the Canadian Arctic Shelf Exchange Study (CASES), led by Louis Fortier (Université Laval). We are indebted to our colleagues for their hard work in many capacities (affiliation at the time of their contribution given in brackets): for field sampling, advice and logistic support: the Fisheries Joint Management Committee (FJMC), DFO, GSC), Aurora Research Institute, the Canadian Hydrographic Service and captains and crews of CCGS Laurier, Radisson, Amundsen and Nahidik; for field collecting assistance, Steve Blasco and Kevin MacKillop (GSC), Humfrey Melling (DFO); Christine McClelland, Karen McKendry and Marie-Hélène Hubert (all CMN), Quinn Eggertson (Carleton University), Megan Foss (University of Victoria), Kate Snow (FJMC) and Philippe Archambault and Mélanie Simard (Université du Québec à Rimouski); for lab processing and faunal identifications: Sheila Edwards, Marie-Hélène Hubert, Karen McKendry, Christine McClelland, Quinn Eggertson, Val Tait (all CMN), Kathryn Wallace (Dalhousie University), Megan Foss (University of Victoria), Phil Lambert (Royal British Columbia Museum) and Pat Pocklington (Arenicola Marine); for GIS mapping, Noel Alfonso (CMN); for water chemistry data, Bill Williams (DFO) and Yves Gratton (INRS-Eau, Terre et Environnement); for sediment analysis, Andrea Freeman (University of Calgary); for literature acquisition, Laura Smyk (CMN). We also thank the reviewers for their constructive criticisms.

Open Access This article is distributed under the terms of the Creative Commons Attribution 4.0 International License (http://creativeco mmons.org/licenses/by/4.0/), which permits unrestricted use, distribution, and reproduction in any medium, provided you give appropriate credit to the original author(s) and the source, provide a link to the Creative Commons license, and indicate if changes were made.

\section{References}

Arrigo KR, van Dijken GL (2004) Annual cycles of sea ice and phytoplankton in Cape Bathurst polynya, southeastern Beaufort Sea, Canadian Arctic. Geophys Res Lett 31:L08304. https://doi. org/10.1029/2003GL018978

Ayles B, Porta L, Clarke RM (2016) Development of an integrated fisheries co-management framework for new and emerging commercial fisheries in the Canadian Beaufort Sea. Mar Policy $72: 246-254$

Barber DG, Hanesiak JM (2004) Meterorological forcing of sea ice concentrations in the southern Beaufort Sea over the period 1979 to 2000. J Geophys Res 109:C06014. https://doi. org/10.1029/2003JC002027

Barber DG, Lukovich JV, Keogak J, Baryluk S, Fortier L, Henry GHR (2008) The changing climate of the Arctic. Arctic 1:7-26

Bellan-Santini D, Dauvin JC (1997) Ampeliscidae (Amphipoda) from Iceland with a description of a new species (Contribution to the BIOICE research programme). J Nat Hist 31:1157-1173

Ben Mustapha SB, Larouche P, Dubois J-M (2010) Does AVHRR-sea surface temperature fronts in the Beaufort Sea, reveal biological hotspots? In: IEEE (ed.) Proceedings of the 2010 IEEE international geoscience and remote sensing symposium. 30th IGARSS 2010, Honolulu, 25-30 July 2010. Institute of Electric and Electronics Engineers, Piscataway, New Jersey, pp 3696-3699

Bluhm BA, Gradinger R (2008) Regional variability in food availability for Arctic marine mammals. Ecol Appl 18(2):S77-S96

Borowsky B, Aitken-Ander P (1991) Sexually dimorphic free-swimming behaviour in the amphipod crustacean Ampelisca abdita. $\mathrm{J}$ Mar Biol Assoc UK 71:655-663

Brandt A (1996) Peracarid crustaceans (Malacostraca) from a "timeseries station" in the westwind trough of the NEW-Polynya (Greenland): a benthic response to productivity? Crustaceana 69:985-1004

Brandt A (1997) Biodiversity of peracarid crustaceans (Malacostraca) from the shelf down to the deep Arctic Ocean. Biodivers Conserv 6:1533-1556

Bray JR, Curtis JT (1957) An ordination of the upland forest communities of southern Wisconsin. Ecol Monogr 27:325-349

Brower AA, Ferguson MC, Schonberg SV, Jewett SC (2017) Gray whale distribution relative to benthic invertebrate biomass and abundance: Northeastern Chukchi Sea 2009-2012. Deep-Sea Res II $144: 156-174$

Buchanan JB (1963) The bottom fauna communities and their sediment relationships off the coast of Northumberland. Oikos 14:154-175

Budnikova LL, Blokhin SA (2012) Food contents of the Eastern Gray Whale Eschrichtius robustus Lilljeborg, 1861 in the Mechigmensky Bay of the Bering Sea. Russ J Mar Biol 38:149-155

Burnham RE, Duffus DA (2016) Gray whale (Eschrichtius robustus) predation and the demise of amphipod prey reserves in Clayoquot Sound, British Columbia. Aquat Mamm 42:123-126. https://doi. org/10.1578/AM.42.2.2016.123

Carmack EC, Kulikov EA (1998) Wind-forced upwelling and internal Kelvin wave generation in Mackenzie Canyon, Beaufort Sea. J Geophys Res 103(C9):18447-18458

Carmack EC, Macdonald RW (2002) Oceanography of the Canadian Shelf of the Beaufort Sea: a setting for marine life. Arctic 55(Suppl 1):29-45

Carmack EC, Macdonald RW, Papadakis JE (1989) Water mass structure and boundaries in the Mackenzie Shelf estuary. J Geophys Res 94(C12):18043-18055

Carmack EC, Macdonald RW, Jasper S (2004) Phytoplankton productivity on the Canadian Shelf of the Beaufort Sea. Mar Ecol Prog Ser 277:37-50

Carmack EC, Yamamoto-Kawai M, Haine TWN, Bacon S, Bluhm BA, Lique C, Melling H, Polyakov IV, Straneo F, Timmermans M-L, Williams WJ (2016) Freshwater and its role in the Arctic Marine system: sources, disposition, storage, export, and physical and biogeochemical consequences in the Arctic and global oceans. J Geophys Res Biogeosci 121:675-717. https://doi. org/10.1002/2015JG003140

Clarke KR, Gorley RN, Somerfield PJ, Warwick RM (2014) Change in marine communities: an approach to statistical analysis and interpretation, 3rd edn. PRIMER-E, Plymouth

Conlan KE, Kvitek RG (2005) Recolonization of soft-sediment ice scours on an exposed Arctic coast. Mar Ecol Prog Ser 286:21-42 
Conlan KE, Aitken A, Hendrycks E, McClelland C, Melling H (2008) Distribution patterns of Canadian Beaufort Shelf macrobenthos. J Mar Syst 74:864-886

Conlan K, Hendrycks E, Aitken A, Williams B, Blasco S, Crawford E (2013) Macrofaunal biomass distribution on the Canadian Beaufort Shelf. J Mar Syst 127:76-87

Coyle KO, Highsmith RC (1989) Arctic ampeliscid amphipods: three new species. J Crustacean Biol 9:157-175

Coyle KO, Highsmith RC (1994) Benthic amphipod community in the northern Bering Sea: analysis of potential structuring mechanisms. Mar Ecol Prog Ser 107:233-244

Coyle KO, Bluhm B, Konar B, Blanchard A, Highsmith RC (2007) Amphipod prey of gray whales in the northern Bering Sea: comparison of biomass and distribution between the $1980 \mathrm{~s}$ and 2002-2003. Deep-Sea Res II 54:2906-2918

Croasdale KR, Marcellus RW (1978) Ice and wave action on artificial islands in the Beaufort Sea. Can J Civ Eng 5:98-113

Cui X, Grebmeier JM, Cooper LW (2012) Feeding ecology of dominant groundfish in the northern Bering Sea. Polar Biol 35:1407-1419

Dauvin J-C, Bellan-Santini D (1990) An overview of the amphipod genus Haploops (Ampeliscidae). J Mar Biol Assoc UK 70:887-903

Dauvin J-C, Zouhiri S (1996) Suprabenthic crustacean fauna of a dense Ampelisca community from the English Channel. J Mar Biol Assoc UK 76:909-929

Dauvin J-C, Alizier S, Weppe A, Guđmundsson G (2012) Diversity and zoogeography of Icelandic deep-sea Ampeliscidae (Crustacea: Amphipoda). Deep-Sea Res I 68:12-23

Dauvin J-C, Bellan-Santini D, Kaïm-Malka R (2017) Importance of systematic in knowledge and protection of biodiversity, the case of the genus Haploops Liljeborg, 1856 (Ampeliscidae). Biodivers J 8:409-410

Dehn L-A, Sheffield GG, Follmann EH, Duffy LK, Thomas DL, O'Hara TM (2007) Feeding ecology of phocid seals and some walrus in the Alaskan and Canadian Arctic as determined by stomach contents and stable isotope analysis. Polar Biol 30:167-181

Demchenko NL, Chapman JW, Durkina VB, Fadeev VI (2016) Life history and production of the Western Gray Whale's prey, Ampelisca eschrichtii Krøyer, 1842 (Amphipoda, Ampeliscidae). PLoS ONE. https://doi.org/10.1371/journal.pone.0147304

Dickinson JJ (1982) Studies on amphipod crustaceans of the Northeastern Pacific Region. I. Family Ampeliscidae, genus Ampelisca. Natl Mus Can Publ Biol Oceanogr 10:1-39

Dickinson JJ (1983) The systematics and distributional ecology of the superfamily Ampeliscoidea (Amphipoda: Gammaridea) in the Northeastern Pacific Region. II. The genera Byblis and Haploops. Natl Mus Can Publ Nat Sci 1:1-38

Dubois SF, Dérian F, Caisey X, Rigolet C, Caprais J-C, Thiébaut E (2015) Role of pockmarks in diversity and species assemblages of coastal macrobenthic communities. Mar Ecol Prog Ser 529:91-105

Durkina VB, Chapman JW, Demchenko NL (2018) Ampelisca eschrichtii Krøyer, 1842 (Ampeliscidae) of the Sakhalin Shelf in the Okhotsk Sea starve in summer and feast in winter. PeerJ 6:e4841. https://doi.org/10.7717/peerj.4841

Ehrhold A, Hamon D, Guillaumont B (2006) The REBENT monitoring network, a spatially integrated, acoustic approach to surveying nearshore macrobenthic habitats: application to the Bay of Concarneau (South Brittany, France). ICES J Mar Sci 63:1604-1615

Enequist P (1949) Studies on the soft-bottom amphipods of the Skagerak. Zool Bidr Upps 28:1-492

Fadeev VI (2011) Benthos studies in feeding grounds of Western Gray Whales off the northeast coast of Sakhalin Island (Russia), 20022010. Paper SC/63/BRG15. International Whaling Commission 63rd Annual Meeting
Feder HM, Naidu AS, Jewett SC, Hameedi JM, Johnson WR, Whitledge TE (1994) The northeastern Chukchi Sea: benthos-environmental interactions. Mar Ecol Prog Ser 111:171-190

Forest A, Tremblay J-E, Gratton Y, Martin J, Gagnon J, Darnis G, Sampei M, Fortier L, Ardyna M, Gosselin M, Hattori H, Nguyen D, Maranger R, Vaqué D, Marrasé C, Pedrós-Alió C, Sallon A, Michel C, Kellogg C, Deming J, Shadwick E, Thomas H, Link H, Archambault P, Piepenburg D (2011) Biogenic carbon flows through the planktonic food web of the Amundsen Gulf (Arctic Ocean): a synthesis of field measurements and inverse modeling analyses. Prog Oceanogr 91:410-436

Franz DR, Tanacredi JT (1992) Secondary production of the amphipod Ampelisca abdita Mills and its importance in the diet of juvenile winter flounder (Pleuronectes americanus) in Jamaica Bay, New York. Estuaries 15:193-203

Franz DR, Worley EK (1982) Seasonal variability of prey in the stomachs of Astropecten americanus (Echinodermata: Asteroidea) from off Southern New England, USA. Estuar Coast Mar Sci $4: 355-368$

Gilbert G, Pedersen K (1987) Ice scour data base for the Beaufort Sea. Environmental Studies Revolving Funds Report No. 055

Gill MJ, Crane K, Hindrum R et al (2011) Arctic marine biodiversity monitoring plan (CBMP-Marine Plan). Arctic Council Open Access Repository. CAFF International Secretariat. http://hdl. handle.net/11374/1067

Giraldo C, Stasko A, Choy ES, Rosenberg B, Majewski A, Power M, Swanson H, Loseto L, Reist JD (2016) Trophic variability of Arctic fishes in the Canadian Beaufort Sea: a fatty acids and stable isotopes approach. Polar Biol 39:1267-1282

Grebmeier JM, Cooper LW (1995) Influence of the St. Lawrence Island Polynya upon the Bering Sea benthos. J Geophys Res 100(C3):4439-4460

Grebmeier JM, Harrison NM (1992) Seabird feeding on benthic amphipods facilitated by gray whale activity in the northern Bering Sea. Mar Ecol Prog Ser 80:125-133

Grebmeier JM, Cooper LW, Feder HM, Sirenko, BI (2006a) Ecosystem dynamics of the Pacific-influenced northern Bering and Chukchi Seas in the Amerasian Arctic. Prog Oceanogr 71:331-361

Grebmeier JM, Overland JE, Moore SE, Farley EV, Carmack EC, Cooper LW, Frey KE, Helle JH, McLaughlin FA, McNutt SL (2006b) A major ecosystem shift in the northern Bering Sea. Science 311:1461-1463

Gurjanova E (1951) Bokoplavy morei SSSR i sopredelnykh vod (Amphipoda, Gammaridea). [Amphipods of the seas of USSR and adjacent waters (Amphipoda, Gammaridea)]. Opredeliteli po faune SSSR, Akademiya Nauk SSSR 41:1-1029

Heide-Jørgensen MP, Laidre KL, Litovka D, Villum Jensen M, Grebmeier JM, Sirenko BI (2012) Identifying gray whale (Eschrichtius robustus) foraging grounds along the Chukotka Peninsula, Russia, using satellite telemetry. Polar Biol 35:1035-1045

Héquette A, Desrosiers M, Barnes PW (1995) Sea ice scouring on the inner shelf of the southeastern Canadian Beaufort Sea. Mar Geol 128:201-219

Highsmith RC, Coyle KO (1990) High productivity of northern Bering Sea benthic amphipods. Nature 344:862-864

Highsmith RC, Coyle KO (1991) Amphipod life histories: community structure, impact of temperature on decoupled growth and maturation rates, productivity, and P: B ratios. Am Zool 31:861-873

Highsmith RC, Coyle KO (1992) Productivity of arctic amphipods relative to gray whale energy requirements. Mar Ecol Prog Ser 83:141-150

Highsmith RC, Coyle KO, Bluhm BA, Konar B (2007) Gray whales in the Bering and Chukchi Seas. In: Estes JA, DeMaster DP, Doak DF, Williams TM, Brownell RL Jr (eds) Whales, whaling, and ocean ecosystems. University of California Press, Berkeley, pp 303-313 
Horton T, Lowry J, De Broyer C et al (2018) World Amphipoda Database. Ampeliscidae Krøyer, 1842. Accessed through: world Register of Marine Species at: http://www.marinespecies.org/aphia .php? $\mathrm{p}=$ taxdetails\&id $=101364$ on 2018-08-24

Iken K, Bluhm B, Dunton K (2010) Benthic food-web structure under differing water mass properties in the southern Chukchi Sea. Deep-Sea Res II 57:71-85

Jenks GF, Caspall FC (1971) Error on choroplethic maps: definition, measurement, reduction. Ann Assoc Am Geogr 61:217-244

Jerosch K (2013) Geostatistical mapping and spatial variability of surficial sediment types on the Beaufort Shelf based on grain size data. J Mar Syst 127:5-13

Jones ML, Swartz SL (2009) Gray whale: Eschrichtius robustus. In: Perrin WF, Würsig BG, Thewissen JGM (eds) Encyclopedia of marine mammals, 2nd edn. Academic Press, London, pp 503-511

Jørgensen LL, Pearson TH, Anisimova NA, Gulliksen B, Dahle S, Denisenko SG, Matishov GG (1999) Environmental influences on benthic fauna associations of the Kara Sea (Arctic Russia). Polar Biol 22:395-416

Kanneworff E (1965) Life cycle, food, and growth of the amphipod Ampelisca macrocephala Liljeborg from the Øresund. Ophelia 2:305-318

Kanneworff E (1966) On some amphipod species of the genus Haploops, with special reference to $H$. tubicola Liljeborg and $H$. tenuis sp. nov. from the Øresund. Ophelia 3:183-207

Kędra M, Moritz C, Choy ES, David C, Degen R, Duerksen S, Ellingsen I, Górska B, Grebmeier JM, Kirievskaya D, van Oevelen D, Piwosz K, Samuelsen A, Węsławski JM (2015) Status and trends in the structure of Arctic benthic food webs. Polar Res 34(1):23775. https://doi.org/10.3402/polar.v34.23775

Kortsch S, Primicerio R, Fossheim M, Dolgov AV, Aschan M (2015) Climate change alters the structure of arctic marine food webs due to poleward shifts of boreal generalists. Proc R Soc B 282:20151546. https://doi.org/10.1098/rspb.2015.1546

Lewis CFM, Blasco SM (1990) Character and distribution of seaice and iceberg scours: keynote address. In: Clark, JI (ed) Workshop on ice scouring and design of offshore pipelines, Calgary, Alberta, April 18-19, 1990. Canada Oil and Gas Lands Administration, Energy, Mines and Resources Canada and Indian and Northern Affairs Canada, pp 57-102

Loring PH, Paton PWC, McWilliams SR, McKinney RA, Oviatt CA (2013) Densities of wintering scoters in relation to benthic prey assemblages in a North Atlantic estuary. Waterbirds 36:144-155

Lukovich JV, Barber DG (2005) On sea ice concentration anomaly coherence in the southern Beaufort Sea. Geophys Res Lett. https ://doi.org/10.1029/2005GL022737

Lyubina OS, Bryazgin VF, Raznovskaya SV (2014) The composition and distribution of benthic amphipods (Crustacea: Amphipoda) in the southern Barents Sea. Russ J Mar Biol 40:241-254. https ://doi.org/10.1134/S1063074014040063

Macdonald RW, Soloman SM, Cranston RE, Welch HE, Yunker MB, Gobeil C (1998) A sediment and organic carbon budget for the Canadian Beaufort Shelf. Mar Geol 144:255-273

Mackenzie CL Jr, Pikanowski R, McMillan DG (2006) Ampelisca amphipod tube mats may enhance abundance of Northern Quahogs Mercenaria mercenaria in muddy sediments. J Shellfish Res 25:841-847

Majewski AR, Atchison S, MacPhee S, Eert J, Niemi A, Michel C, Reist JD (2017) Marine fish community structure and habitat associations on the Canadina Beaufort shelf and slope. Deep-Sea Res I 121:169-182. https://doi.org/10.1016/j.dsr.2017.01.009

McDermott JJ, Snyder RL (1988) Food and feeding behaviour of the hoplonemertean Oerstedia dorsalis. Hydrobiologia 156:47-51
McKeague JA (1976) Manual of soil sampling and methods of analysis. Soil Research Institute, Research Branch. Agriculture Canada, Ottawa

McTigue ND, Dunton KH (2017) Trophodynamics of the Hanna Shoal Ecosystem (Chukchi Sea, Alaska): connecting multiple end-members to a rich food web. Deep-Sea Res II 144:175-189

Melling H, Francois R, Myers PG, Perrie W, Rochon A, Taylor RL (2012) The Arctic Ocean-a Canadian perspective from IPY. Clim Change 115:89-113. https://doi.org/10.1007/s1058 4-012-0576-4

Mills EL (1965) The zoogeography of North Atlantic and North Pacific ampeliscid amphipod crustaceans. Syst Zool 14:119-130

Mills EL (1967) A reexamination of some species of Ampelisca (Crustacea: Amphipoda) from the east coast of North America. Can J Zool 45:635-652

Mills EL (1971) Deep-sea Amphipoda from the western North Atlantic Ocean. The family Ampeliscidae. Limnol Oceanogr 16:357-386

Mironov AN (2013) Biotic complexes of the Arctic Ocean. Invertebr Zool 10:3-48

Moore SE, Grebmeier JM, Davies JR (2003) Gray whale distribution relative to forage habitat in the northern Bering Sea: current conditions and retrospective summary. Can J Zool 81:734-742

Moore SE, Logerwell E, Eisner L, Farley EV Jr, Harwood LA, Kuletz K, Lovvorn J, Murphy JR, Quakenbush LT (2014) Marine fishes, birds and mammals as sentinels of ecosystem variability and reorganization in the Pacific Arctic Region. In: Grebmeier J, Maslowski W (eds) the Pacific Arctic Region. Springer, Dordrecht, pp 337-392

Moore GWK, Schweiger A, Zhang J, Steele M (2018) Collapse of the 2017 Winter Beaufort High: a response to thinning sea ice? Geophys Res Lett 45:2860-2869. https://doi.org/10.1002/2017G L076446

Morata N, Renaud PE, Brugel S, Hobson KA, Johnson BJ (2008) Spatial and seasonal variations in the pelagic-benthic coupling of the southeastern Beaufort Sea revealed by sedimentary biomarkers. Mar Ecol Prog Ser 371:47-63

Myers R, Blasco S, Gilbert G, Shearer J (1996) 1990 Beaufort Sea ice scour repetitive mapping program, vol 1. Environmental Studies Research Funds Report No. 129

Myers AA, Rigolet C, Thiébaut E, Dubois SF (2012) A new species of amphipod, Photis inornatus sp. nov. (Corophiidea, Photidae) from a 'Haploops community' in Brittany. Zootaxa 3236:55-61

National Snow and Ice Data Center (2018) September 4, 2018. No endless summer in the Arctic. Arctic Sea Ice News \& Analysis. http://nsidc.org/arcticseaicenews/. Accessed 11 Sept 2018

Oliver JS, Slattery PN (1985) Destruction and opportunity on the sea floor: effects of gray whale feeding. Ecology 66:1965-1975

Oliver JS, Slattery PN, Silberstein MA, O'Connor EF (1984) Gray whale feeding on dense ampeliscid amphipod communities near Bamfield, British Columbia. Can J Zool 62:41-49

Peart RA (2018) Ampeliscidae (Crustacea. ZooKeys, Amphipoda) from the IceAGE expeditions. https://doi.org/10.3897/zooke ys.731.19948

Petty AA (2018) A possible link between winter Arctic sea ice decline and a collapse of the Beaufort high? Geophys Res Lett 45:28792882. https://doi.org/10.1002/2018GL077704

Poggiale J-C, Dauvin J-C (2001) Long-term dynamics of three benthic Ampelisca (Crustacea-Amphipoda) populations from the Bay of Morlaix (western English Channel) related to their disappearance after the 'Amoco Cadiz' oil spill. Mar Ecol Prog Ser 214:201-209

Rees DJ, Dufresne F, Glémet H, Belzile C (2007) Amphipod genome sizes: first estimates for Arctic species reveal genomic giants. Genome 50:151-158 
Renaud PE, Morata N, Ambrose WG Jr, Bowie JJ, Chiuchiolo A (2007a) Carbon cycling by seafloor communities on the eastern Beaufort Sea shelf. J Exp Mar Biol Ecol 349:248-260

Renaud PE, Riedel A, Michel C, Morata N, Gosselin M, Juul-Pedersen T, Chiuchiolo A (2007b) Seasonal variation in benthic community oxygen demand: a response to an ice algal bloom in the Beaufort Sea, Canadian Arctic? J Mar Syst 67:1-12

Renaud PE, Sejr MK, Bluhm BA, Sirenko B, Ellingsen IH (2015) The future of Arctic benthos: expansion, invasion, and biodiversity. Prog Oceanogr 139:244-257

Rigolet C, Le Souchu P, Caisey X, Dubois SF (2011) Group sweeping: feeding activity and filtration rate in the tubiculous amphipod Haploops nirae (Kaim-Malka, 1976). J Exp Mar Biol Ecol 406:29-37

Rigolet C, Dubois SF, Droual G, Caisey X, Thiébaut E (2012) Life history and secondary production of the amphipod Haploops nirae (Kaim-Malka, 1976) in the Bay of Concarneau (South Brittany). Estuar Coast Mar Sci 113:259-271

Rigolet C, Dubois SF, Thiébaut E (2014a) Benthic control freaks: effects of the tubiculous amphipod Haploops nirae on the specific diversity and functional structure of benthic communities. J Sea Res 85:413-427

Rigolet C, Thiébaut E, Dubois SF (2014b) Food web structures of subtidal benthic muddy habitats: evidence of microphytobenthos contribution supported by an engineer species. Mar Ecol Prog Ser 500:25-41

Sampei M, Sasaki H, Makabe R, Forest A, Hattori H, Tremblay J-E, Gratton Y, Fukuchi M, Fortier L (2011) Production and retention of biogenic matter in the southeast Beaufort Sea during 20032004: insights from annual vertical particle fluxes of organic carbon and biogenic silica. Polar Biol 34:501-511

Schiffman R (2016) Why are gray whales moving to the ocean next door? DiscoverMagazine, April 2016 Issue. http://discoverma gazine.com/2016/april/13-why-are-gray-whales-moving-to-theocean-next-door. Accessed 6 Dec 2017

Schonberg SV, Clarke JT, Dunton KH (2014) Distribution, abundance, biomass and diversity of benthic infauna in the Northeast Chukchi Sea, Alaska: relation to environmental variables and marine mammals. Deep-Sea Res II 102:144-163

Schuman GE, Stanley MA, Knudsen D (1973) Automated total nitrogen analysis of soil and plant samples. Soil Sci Soc Am Pro 37:480-481

Sheader M (1998) Grazing predation on a population of Ampelisca tenuicornis (Gammaridae: Amphipoda) off the south coast of England. Mar Ecol Prog Ser 164:253-262

Simpson KG, Tremblay J-É, Brugel S, Price NM (2013a) Nutrient dynamics in the western Canadian Arctic. II. Estimates of new and regenerated production over the Mackenzie Shelf and Cape Bathurst Polynya. Mar Ecol Prog Ser 484:47-62. https://doi. org/10.3354/meps10298

Simpson KG, Tremblay J-É, Price NM (2013b) Nutrient dynamics in the western Canadian Arctic. I. New production in spring inferred from nutrient draw-down in the Cape Bathurst Polynya. Mar Ecol Prog Ser 484:33-45. https://doi.org/10.3354/meps1 0275
Somerfield PJ, Clarke KR (2013) Inverse analysis in non-parametric multivariate analyses: distinguishing groups of associated species which covary coherently across samples. J Exp Mar Biol Ecol 449:261-273

Sudo H, Azeta M (1992) Selective predation on mature male Byblis japonicus (Amphipoda: Gammaridea) by the barface cardinalfish, Apogon semilineatus. Mar Biol 114:211-217

Tooth M, Tschudi M (2018) Investigating Arctic sea ice survivability in the Beaufort Sea. Remote Sens 10:267. https://doi.org/10.3390/ rs 10020267

Tremblay J-É, Bélanger S, Barber DG, Asplin M, Martin J, Darnis G, Fortier L, Gratton Y, Link H, Archambault P, Sallon A, Michel C, Williams WJ, Philippe B, Gosselin M (2011) Climate forcing multiplies biological productivity in the coastal Arctic Ocean. Geophys Res Lett. https://doi.org/10.1029/2011GL048825

Tu KL, Blanchard AL, Iken K, Horstmann-Dehn L (2015) Smallscale spatial variability in benthic food webs in the northeastern Chukchi Sea. Mar Ecol Prog Ser 528:19-37. https://doi. org/10.3354/meps 11216

Villegas-Amtmann S, Schwarz LK, Gailey G, Sychenko O, Costa DP (2017) East or west: the energetic cost of being a gray whale and the consequence of losing energy to disturbance. Endang Species Res. https://doi.org/10.3354/esr00843

Walkusz W, Williams WJ, Harwood LA, Moore SE, Stewart BE, Kwasniewski S (2012) Composition, biomass and energetic content of biota in the vicinity of feeding bowhead whales (Balaena mysticetus) in the Cape Bathurst upwelling region (south eastern Beaufort Sea). Deep-Sea Res I 69:25-35

Walkusz W, Williams WJ, Kwasniewski S (2013) Vertical distribution of mesozooplankton in the coastal Canadian Beaufort Sea in summer. J Mar Syst 127:26-35

Wassmann P, Duarte CM, Agustí S, Sejr MK (2011) Footprints of climate change in the Arctic marine ecosystem. Glob Change Biol 17:1235-1249. https://doi.org/10.1111/j.1365-2486.2010.02311 . $\mathrm{x}$

Wildish DJ (1984) Secondary production of four sublittoral, soft sediment amphipod populations in the Bay of Fundy. Can J Zool 62:1027-1033

Williams WJ, Carmack EC (2008) Combined effect of wind-forcing and isobath divergence on upwelling at Cape Bathurst, Beaufort Sea. J Mar Res 66:645-663

Williams WJ, Carmack EC, Shimada K, Melling H, Aagaard K, Macdonald RW, Ingram RG (2006) Joint effects of wind and ice motion in forcing upwelling in Mackenzie Trough, Beaufort Sea. Cont Shelf Res 26:2352-2366

Williams WJ, Melling H, Carmack EC, Ingram RG (2008) Kugmallit Valley as a conduit for cross-shelf exchange on the Mackenzie Shelf in the Beaufort Sea. J Geophys Res 113:C02007. https:// doi.org/10.1029/2006JC003591

Zimmer C (2015) Whales on the wrong side of the world. National Geographic. Phenomena: The Loom. http://phenomena.natio nalgeographic.com/2015/03/10/whales-on-the-wrong-side-ofthe-world/. Accessed 6 Dec 2017 